Review

\title{
Microbial Conversion of Waste Glycerol from Biodiesel Production into Value-Added Products
}

\author{
Cheng Li, Keaton L. Lesnik and Hong Liu * \\ Department of Biological and Ecological Engineering, Oregon State University, 116 Gilmore Hall, \\ Corvallis, OR 97331, USA; E-Mails: lichen@onid.orst.edu (C.L.); lesnikk@onid.orst.edu (K.L.L.) \\ * Author to whom correspondence should be addressed; E-Mail: liuh@engr.orst.edu; \\ Tel.: +1-541-737-6309; Fax: +1-541-737-2082.
}

Received: 6 June 2013; in revised form: 19 July 2013 / Accepted: 4 September 2013 / Published: 10 September 2013

\begin{abstract}
Biodiesel has gained a significant amount of attention over the past decade as an environmentally friendly fuel that is capable of being utilized by a conventional diesel engine. However, the biodiesel production process generates glycerol-containing waste streams which have become a disposal issue for biodiesel plants and generated a surplus of glycerol. A value-added opportunity is needed in order to compensate for disposal-associated costs. Microbial conversions from glycerol to valuable chemicals performed by various bacteria, yeast, fungi, and microalgae are discussed in this review paper, as well as the possibility of extending these conversions to microbial electrochemical technologies.
\end{abstract}

Keywords: biodiesel waste glycerol; microbial conversion; 1,3-propanediol; ethanol; lactic acid; hydrogen; citric acid; microbial electrochemical technologies

\section{Introduction}

Consumption of fossil energy is the foundation of modern society, from moving vehicles to lighting bulbs. However, many concerns have been raised about refining efficiency, effects on climate change, air pollution, and diminishing fossil fuel deposits [1]. Biodiesel is a fast growing alternative fuel that can be applied to a conventional diesel engine. The biodiesel demand is clearly increasing in the United States as annual production of biodiesel in 2012 (969 million gallons) was 2.83 times higher than in 2010 (343 million gallons) [2]. Furthermore, under a mandate by the renewable fuels standard 
(RFS2) of the U.S. Energy Independence and Security Act of 2007, biomass-based diesel production is expected to increase to 36 billion by 2022 [3].

The flow chart of biodiesel production is shown in Figure 1. Biodiesel is an environmentally attractive alternative fuel, which compared to petro-diesel, holds technical advantages like inherent lubricity, low toxicity, biodegradability, renewability, etc. Biodiesel itself is composed of mono-alkyl esters of vegetable oils or animal fats and is produced by transesterification with a monohydric alcohol (methanol) [3]. During the transesterification reaction, the glycerol backbone of triacylglycerol is substituted by methanol in the presence of a catalyst at elevated temperature, leaving fatty acid alkyl esters and glycerol as the major liquid products. Waste glycerol, the liquid content after methanol recovery, has a $\mathrm{pH}$ around 10 and viscosity from 1213 to $1515 \mathrm{mPa} \cdot \mathrm{s}$ [4]. The glycerol content in waste glycerol is from $27 \mathrm{wt} \%$ to $28 \mathrm{wt} \%$ with a methanol concentration that can vary from $6.2 \mathrm{wt} \%$ to $12.6 \mathrm{wt} \%$. Trace amounts of soap formed in an undesirable saponification reaction can also be found in waste glycerol [4]. Previously, commercial glycerol synthesis was primarily performed by propylene chlorine hydrolyzation in caustic environments [5]. Nowadays, the chemical synthesis of glycerol only accounts for about $10 \%$ of the current market because of the increasing cost of petrochemical precursors and decreasing price of pure glycerol [6]. In the past few years, the price of refined glycerol had dropped from $\$ 1.15$ per kilogram to $\$ 0.66$ per kilogram while the price of waste glycerol has also dropped from $\$ 0.44$ to $\$ 0.11$ per kilogram $[1,7]$. The expansion of the biodiesel industry has thus created a surplus of glycerol, resulting in an inevitable abundance of waste glycerol now considered as a waste stream with associated disposal costs [6]. Therefore, the need to find efficient approaches to convert waste glycerol into more desirable products is urgent and necessary.

Figure 1. Scheme of biodiesel production and waste glycerol (adapted from [6]).

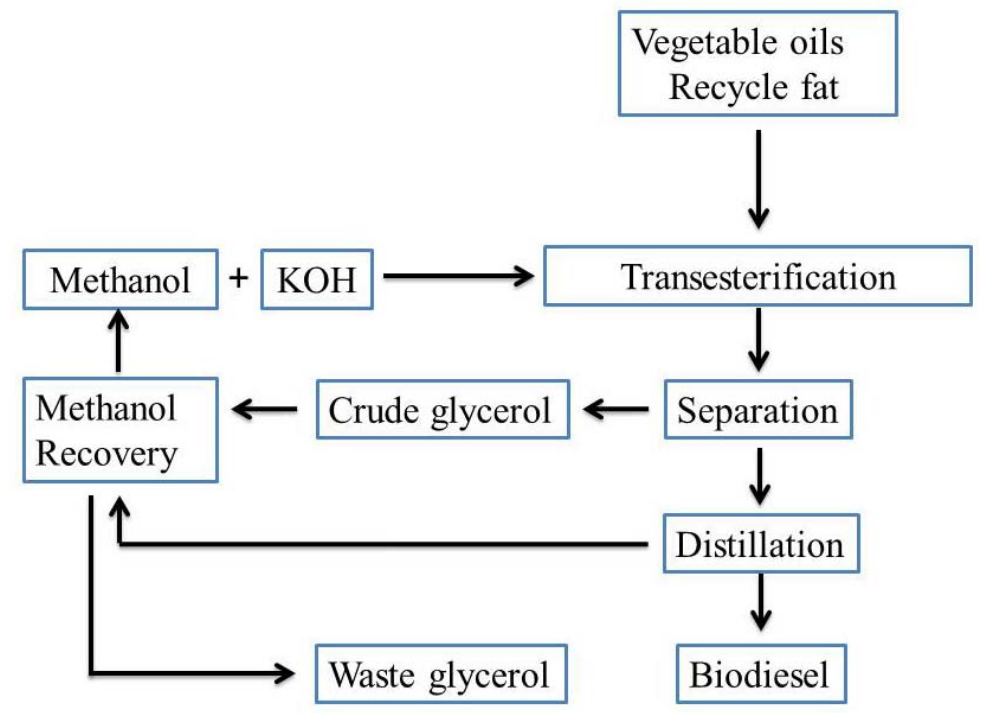

Value-added transformation processes of waste glycerol can be accomplished by direct application, chemical transformation, or microbial conversion [1,8-10]. Direct application refers to processes without any catalytic reaction, instead treating waste glycerol as a simple carbon source. One particular example of direct application is using biodiesel waste glycerol in animal feed $[1,11]$. However, some impurities within waste glycerol like methanol and potassium may result in harmful effects to animals, and thus concentrations need to be controlled [1]. Chemical transformation can be understood 
through three major approaches: (1) oxidation/reduction of glycerol into other 3-carbon compounds; (2) synthesis of higher carbon compounds with glycerol and other substrates; and (3) industrial combustion [9]. These traditional chemical catalytic processes often include expensive metal catalysts, toxic intermediates, and low conversion rates [9]. Moreover, it is difficult to combust glycerol efficiently due to its low energy density, high viscosity, high auto-ignition temperature, and potential emission problems [8]. Compared to direct application and chemical transformation, microbial conversion is a viable alternative that avoids certain disadvantages such as low product specificity, high energy input (pressure/temperature) and intensive pretreatment requirements $[1,6]$. On the other hand, compared to conventional biorefinery substrates, such as glucose and sucrose, waste glycerol presents a class of substrates that are inexpensive, sustainable, and not considered a suitable human food source. In addition, glycerol has a higher degree of reductant and NADH generation rate than other common microbial feedstocks. Consuming one mole of glycerol generates two additional moles of NADH, while consuming a half mole of glucose (equally on a 3-carbon basis) only generates one additional mole of NADH $[12,13]$.

With the development of the biodiesel industry, new breakthroughs have been made each year using different microbial species and bioengineering techniques to convert waste glycerol to value-added products. There are several excellent reviews published in the past several years with a focus on specific products, microbial species, or chemical catalytic processes $[1,6,9,14,15]$. In this review, the glycerol metabolic pathways of representative bacterial and yeast species will be comprehensively discussed. This includes the capability of various microbial species to convert glycerol to value-added chemicals addressed in terms of yield, productivity and final concentration. We also introduced and discussed microbial electrochemical technologies that may be used as a strategy for generating value-added chemicals as well as electrical energy directly from glycerol.

\section{Microbial Conversion of Glycerol}

\subsection{Fermentation of Glycerol by Enterobacteriaceae Family}

Enterobacteriaceae is a large family of gram-negative bacteria that includes Escherichia, Klebsiella, and Citrobacter among others [16]. The glycerol utilization pathways in Entrerobacteriaceae have been intensively studied with the goal of industrial production of 1,3-propanediol (1,3-PDO) [6]. These pathways may also be applied to some other bacteria that contain similar metabolic grids. Figure 2 illustrates the general metabolic pathways for glycerol utilization in Entrerobacteriaceae. 
Figure 2. Prokaryotic pathway of glycerol utilization in Entrerobacteriaceae species (adapted from [4,17]). Enzymes: ACK, acetate kinase; ADH, acetaldehyde/alcohol dehydrogenase; AOR, aldehyde oxidoreductase; DHAK, dihydroxyacetone kinase; FHL, formate hydrogen lyase complex; FRD, fumarate reductase; GlyD, glycerol dehydratase; glyDH, glycerol dehydrogenase; glpF, glycerol transporter, LALDH, lactaldehyde dehydrogenase; LDH, lactate dehydrogenase; MGR, methylglyoxal reductase; MGS, methylglyoxal synthase; PFL, pyruvate formate-lyase; PEPCK, phosphoenolpyruvate carboxykinase; PTA, phosphate acetyltransferase; PYK, pyruvate kinase; 1,2-PDOR, 1,2-propanediol reductase; 1,3-PDODH, 1,3-propanediol dehydrogenase. Chemical intermediates and products: DHA, dihydroxyacetone; DHAP, dihydroxyacetone phosphate; FUM, fumarate; GAL3P, glyceraldehyde-3-phosphate; 3HPA, 3-hydroxypropionaldehyde; MAL, malate; OAA, oxaloacetate; PEP, phosphoenolpyruvate; PYR, pyruvate; 1,2-PDO, 1,2-propanediol; 1,3-PDO, 1,3-propanediol. (Dash line indicates reactions for 1,2-PDO pathway; filled box indicates potential products).

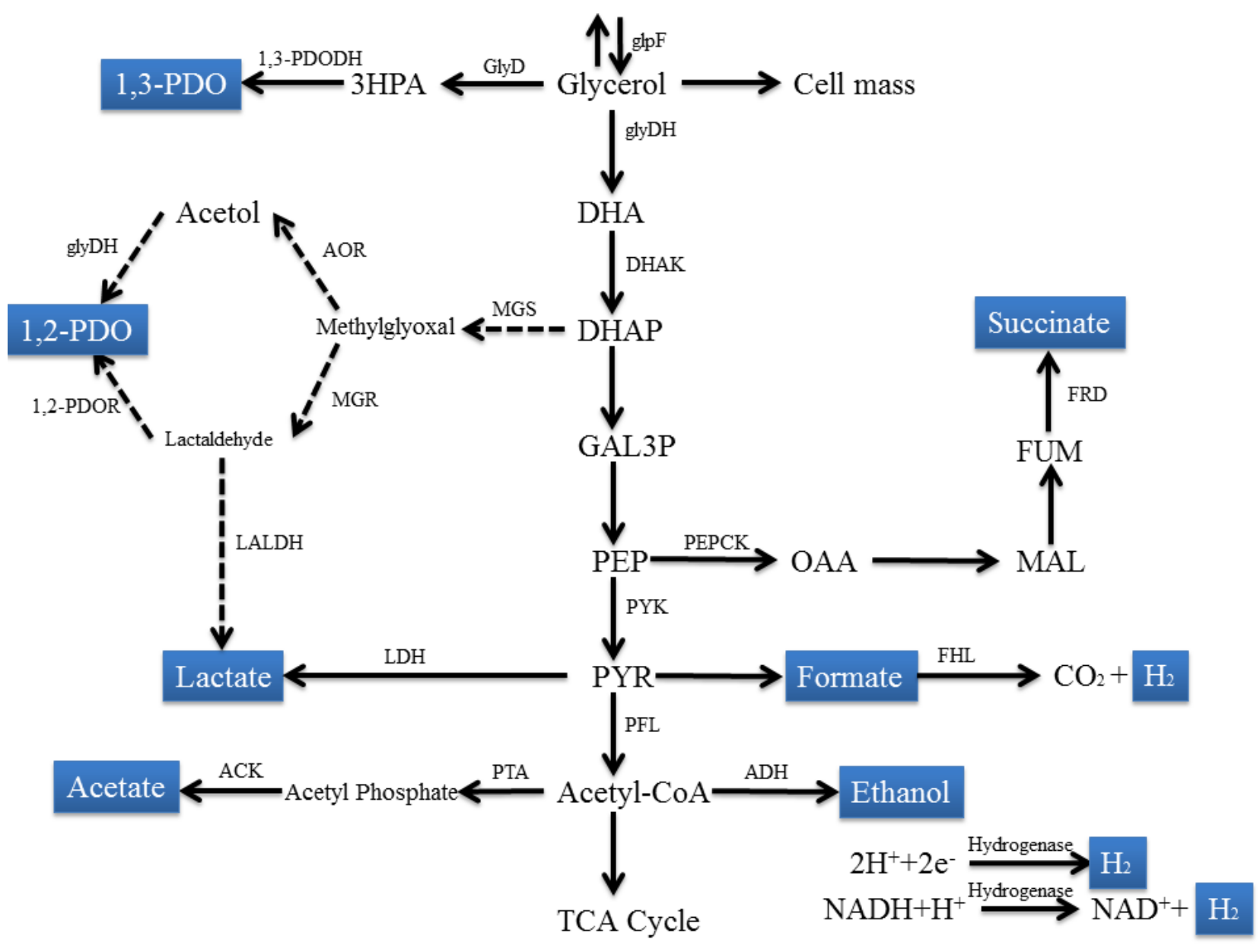

Glycerol can be actively transported inside the cytoplasm by a transporter protein (glpF) [18], known as a glycerol facilitator [19]. Intracellular glycerol is converted to dihydroxyacetone (DHA) by a $\mathrm{NAD}^{+}$-dependent glycerol dehydrogenase (glyDH), and then phosphorylated to dihydroxyacetone phosphate (DHAP) by a phosphoenolpyruvate (PEP) dependent DHA kinase (DHAK) [6]. DHAP is further oxidized through glycolysis to form building blocks like phosphoenolpyruvate (PEP), pyruvate 
(PYR), and acetyl-CoA. The high-energy molecule PEP can be converted to oxaloacetate by phosphoenolpyruvate carboxykinase and then reduced stepwise to succinate in the presence of certain enzymes involved in the TCA cycle. Pyruvate can then be reduced to lactate by lactate dehydrogenase (LDH). Acetyl-CoA can be converted to acetate by both phosphate acetyltransferase (PTA) and acetate kinase (ACK), or be reduced to ethanol by acetaldehyde/alcohol dehydrogenase (ADH).

The reductive pathways act as an electron sink for oxidation, consuming reducing equivalents generated during the stepwise oxidation of glycerol to achieve redox balance. Differing from other substrates, glycerol has a high degree of reductant, therefore one particular challenge for glycerol fermenting species is the consumption of excess reducing equivalent [20]. A $\mathrm{B}_{12}$-dependent glycerol dehydratase (GlyD) and a 1,3-propanediol dehydrogenase (1,3-PDODH) were identified in the reductive pathway for this purpose [21]. The 1,2-propanediol (1,2-PDO) pathway, which is present primarily in Escherichia coli strains, might act as an alternative mechanism for cells to regenerate $\mathrm{NAD}^{+}$[22]. During the reductive pathway, some of the electrons can be diverted to combine with protons and released as hydrogen gas under anaerobic conditions and low partial pressure of hydrogen [23]. It is also suggested that an acetaldehyde/alcohol dehydrogenase might carry out an important role in glycerol fermentation for regaining redox balance [18].

\subsubsection{Escherichia Species}

As the most well-studied member in Enterobacteriaceae family, both wild type and engineered strains of Escherichia coli can be considered a bacterial platform for producing value-added metabolites [24]. Glycerol fermentation performed by Escherichia coli can produce ethanol, lactic acid, 1,2-PDO, 1,3-PDO, and succinic acid, all of which represent value-added opportunities.

Ethanol is typically formed to fulfill the energy requirement of a bacterial cell. Ethanol can also serve as a direct fuel or as a gasoline additive for its octane booster effect [25], though ethanol conversion rates by wild type $E$. coli are often not high enough to satisfy the needs of industrial production [18,22]. To maximize ethanol production, strain SY03 was constructed by inactivating enzymes responsible for succinate and acetate synthesis (fumarate reductase and phosphate acetyltransferase). This strain was shown to be capable of producing 1 mole of ethanol and 1 mole of hydrogen gas per mole of glycerol consumed [26] (Table 1). 
Table 1. Microbial conversion of glycerol to value-add products.

\begin{tabular}{|c|c|c|c|c|c|c|}
\hline Bacterial species & Strain & Product & Yield (mol/mol glycerol) & Productivity (g/L/h) & Final concentration $(\mathrm{g} / \mathrm{L})$ & Ref. \\
\hline \multirow{8}{*}{ Escherichia coli } & Engineered E. coli SY03 & Ethanol & 1 & 0.051 & 5 & [26] \\
\hline & E. coli AC521 & Lactic acid & 0.9 & 0.97 & 85.8 & [27] \\
\hline & Engineered E. coli & D-lactic acid & 0.82 (pure glycerol) & 1.5 (pure glycerol) & 32 (pure glycerol) & [28] \\
\hline & & & 0.87 (waste glycerol) & & 34 (waste glycerol) & \\
\hline & Engineered E. coli & L-lactic acid & 0.91 & - & 50 & [29] \\
\hline & Engineered E. coli & 1,2-PDO & 0.26 & - & 5.6 & [30] \\
\hline & Engineered E. coli & 1,3-PDO & 1.09 & 2.61 & 104.4 & [31] \\
\hline & Engineered E. coli & Succinate & 0.8 & - & 12 & [32] \\
\hline \multirow{7}{*}{ Klebsiella } & K. pneumonia (Encapsulated) & 1,3-PDO & 0.65 (batch) & 4.46 (continuous) & - & [33] \\
\hline & & & 0.43 (continuous) & & & \\
\hline & K. pneumonia (Pilot scale) & 1,3-PDO & 0.58 & 0.92 & 58.8 & [34] \\
\hline & K. oxytoca (Lactate deficient) & 1,3-PDO & $0.41-0.53$ & $0.63-0.83$ & - & [35] \\
\hline & K. pneumonia (Inactivated ADH) & 1,3-PDO & 0.70 & 1.07 & - & [36] \\
\hline & K. pneumonia & 2,3-BD & 0.36 & 0.18 & 49.2 & [37] \\
\hline & Engineered $K$. pneumonia & Ethanol & 0.89 & 1.2 & 31.0 & [38] \\
\hline \multirow{4}{*}{ Citrobacter } & C. freundii FMCC-B294 & 1,3-PDO & 0.48 & 0.79 & 68.1 & [39] \\
\hline & C. werkmanii DSM 17579 & 1,3-PDO & 0.62 & 2.84 & - & [40] \\
\hline & C. freundii $\mathrm{H} 3$ & $\mathrm{H}_{2}$ & 0.94 & - & - & [41] \\
\hline & Engineered C. freundii & Violacein & - & $82.6 \mathrm{mg} / \mathrm{L} / \mathrm{h}$ & 4.13 & [42] \\
\hline
\end{tabular}


Table 1. Cont.

\begin{tabular}{|c|c|c|c|c|c|c|}
\hline Bacterial species & Strain & Product & Yield (mol/mol glycerol) & Productivity (g/L/h) & Final concentration $(g / L)$ & Ref. \\
\hline \multirow{6}{*}{ Clostridium } & C. butyricum VPI 3266 & 1,3-PDO & 0.65 & 10.3 & - & [43] \\
\hline & C. butyricum AKR102a & 1,3-PDO & 0.63 (pure glycerol) & 3.3 (pure glycerol) & 93.7 (pure glycerol) & [44] \\
\hline & C. butyricum VPI 1718 & 1,3-PDO & 0.665 & - & 67.9 & [45] \\
\hline & Engineered C. acetobutylicum & 1,3-PDO & 0.66 & 3 & - & [46] \\
\hline & C. pasteurianam (immobilized) & n-butanol & 0.43 & 0.074 & 8.84 & [47] \\
\hline & C. pasteurianam ATCC 6013 & $\begin{array}{l}1,3-\mathrm{PDO} \text { and } \\
\text { butanol }\end{array}$ & $\begin{array}{l}0.17 \text { (1,3-PDO) } \\
0.28 \text { (butanol) }\end{array}$ & $\begin{array}{l}0.42(1,3-P D O) 2.49 \\
\text { (butanol) }\end{array}$ & - & [48] \\
\hline \multirow{2}{*}{$\begin{array}{l}\text { Propionibacterium } \\
\text { bacteria }\end{array}$} & $\begin{array}{l}\text { Engineered } P \text {. acidipropionici } \\
\text { strain }\end{array}$ & Propionic acid & $\begin{array}{l}0.66 \text { (pure glycerol), } \\
0.88 \text { (waste glycerol) }\end{array}$ & $\begin{array}{l}0.10 \text { (pure glycerol), } \\
0.085 \text { (waste glycerol) }\end{array}$ & 106 (pure glycerol) & [49] \\
\hline & $\begin{array}{l}\text { P. freudenreichi subsp. } \\
\text { Shermanii NCIM } 5137\end{array}$ & Trehalose & $391 \mathrm{mg} / \mathrm{g}$ biomass & - & - & {$[50]$} \\
\hline \multirow{12}{*}{$\begin{array}{l}\text { Other bacteria and } \\
\text { mixed culture }\end{array}$} & R. palustris CGA009 & $\mathrm{H}_{2}$ & 6 & - & - & [51] \\
\hline & P. macerans & $\mathrm{H}_{2}$ & 0.801 & - & - & [52] \\
\hline & Thermoanaerobacterium sp. & $\mathrm{H}_{2}$ & 0.30 & - & - & [53] \\
\hline & Mixed culture & $\mathrm{H}_{2}$ & 0.96 & $91 \mathrm{~mL} / \mathrm{L} / \mathrm{h}$ & - & [54] \\
\hline & Mixed culture & $\mathrm{H}_{2} /$ formate & 0.80 & - & - & [55] \\
\hline & Mixed culture & $\mathrm{H}_{2}$ & $\begin{array}{l}0.28 \text { (pure glycerol) } \\
0.31 \text { (waste glycerol) }\end{array}$ & - & - & [23] \\
\hline & L. acidophilus & Probiotic cell mass & $0.37 \mathrm{~g} / \mathrm{g}$ & - & 2.11 & \\
\hline & L. diolivorans & 1,3-PDO & - & - & 73.7 & \\
\hline & Anaerobic co-digestion & Biogas & - & - & $1210 \mathrm{~mL} / \mathrm{d}$ & [56] \\
\hline & C. necator DSM 545 & PHAs & - & 1.1 & - & [57] \\
\hline & Z. denitrificans MW1 & PHAs & $0.31 \mathrm{~g} / \mathrm{g}$ glycerol & - & - & [58] \\
\hline & P. putida GO16 & PHAs & - & 0.11 & - & [59] \\
\hline
\end{tabular}


Table 1. Cont

\begin{tabular}{|c|c|c|c|c|c|c|}
\hline Bacterial species & Strain & Product & Yield (mol/mol glycerol) & Productivity (g/L/h) & Final concentration $(g / L)$ & Ref. \\
\hline \multirow{9}{*}{ Yeasts } & Y. lipolytica NCIM 3589 & Citric acid & - & - & 77.4 & [60] \\
\hline & Y. lipolytica Wratislavia AWG7 & Citric acid & 0.33 & 1.16 & 139 & [61] \\
\hline & C. bombicola ATCC 22214 & Sophorolipids & - & - & 60 & [62] \\
\hline & P. antarctica JCM 10317 & $\begin{array}{l}\text { Mannosylerythritol } \\
\text { lipid }\end{array}$ & - & - & 16.3 & {$[63]$} \\
\hline & Cryptococcus curvatus & SCO & $52 \%$ lipid content & - & 17.1 & [64] \\
\hline & Rhodotorula glutinis & $\mathrm{SCO}$ & $36.5 \%$ lipid content & - & 5.4 & [65] \\
\hline & S. ruberrimus CSB 2636 & Carotenoid & $41.9 \mu \mathrm{g} / \mathrm{g}$ glycerol, & $56.9 \mu \mathrm{g} / \mathrm{L} / \mathrm{h}$ & $3425.9 \mu \mathrm{g} / \mathrm{L}$ & [66] \\
\hline & Engineered $S$. cerevisiae & Ethanol & - & - & $2.4 \mathrm{~g} / \mathrm{L}$ & [67] \\
\hline & Engineered $S$. cerevisiae & 1,2-PDO & 0.258 & - & 2.19 & [68] \\
\hline \multirow{6}{*}{ Fungi } & L. edodes strains & $\mathrm{SCO}$ & $0.1 \mathrm{~g} / \mathrm{g}$ biomass & - & 0.52 & [69] \\
\hline & A. niger strains & SCO & 0.41 to $0.57 \mathrm{~g} / \mathrm{g}$ biomass & - & 3.1 to 3.5 & [69] \\
\hline & Galactomyces geotrichum & SCO & $0.44 \mathrm{~g} / \mathrm{g}$ biomass & - & - & [70] \\
\hline & Thamnidium elegans & $\mathrm{SCO}$ & - & - & 11.6 & [71] \\
\hline & Pythium irregulare & EPA & - & $14.9 \mathrm{mg} / \mathrm{L} /$ day & $90 \mathrm{mg} / \mathrm{L}$ & [72] \\
\hline & Blakeslea trispora & $\beta$-carotene & $15 \mathrm{mg} / \mathrm{g}$ biomass & - & - & [73] \\
\hline Microalgae & S. limacinum SR21 & DHA & - & 0.51 & - & [74] \\
\hline \multirow{6}{*}{$\begin{array}{l}\text { Microbial } \\
\text { Electrochemical } \\
\text { Technology }\end{array}$} & B. subtilis MFC & Electricity & \multicolumn{3}{|c|}{ Maximum power density $600 \mathrm{~mW} / \mathrm{m}^{2}$} & [75] \\
\hline & Single chamber MFC & Electricity & \multirow{2}{*}{\multicolumn{3}{|c|}{$\begin{array}{l}\text { Maximum power density } 2110 \mathrm{~mW} / \mathrm{m}^{2} \\
\text { Maximum power density } 4579 \mathrm{~mW} / \mathrm{m}^{3} \text { with pure glycerol, } 2324 \mathrm{~mW} / \mathrm{m}^{3} \text { with waster } \\
\text { glycerol }\end{array}$}} & [76] \\
\hline & Single chamber MFC & Electricity & & & & [77] \\
\hline & E. aerogenes MEC & $\mathrm{H}_{2}$ & 0.74 & - & - & [78] \\
\hline & Mixed culture MEC & $\mathrm{H}_{2}$ & 3.9 & - & - & [79] \\
\hline & MEC with gas phase cathode & $\mathrm{H}_{2}$ & 5.4 & $0.6 \mathrm{~L} / \mathrm{L} / \mathrm{day}$ & - & [80] \\
\hline
\end{tabular}


Lactic acid can be produced during glycerol fermentation by some $E$. coli strains as an alternative to $\mathrm{NAD}^{+}$regeneration in the absence of external electron acceptors [27]. Lactic acid has many applications as a food additive, acidulant, as well in the production of biodegradable polylactic acid [81,82]. Food-grade lactic acid has a price ranging between $\$ 1.38$ per kilogram (50\% purity) and $\$ 1.88$ per kilogram (88\% purity) [83,84]. Compared to traditional chemical synthesis methods, microbial conversion of lactic acid favors the formation of one specific configuration, either D- or L-, due to the high specificity of lactate dehydrogenase (LDH) [28,29], a property that can simplify downstream processes such as separation and purification. High chiral purity of D-lactate can be produced by fermenting glycerol using a recombinant strain that overexpresses enzymes that respond to glycolytic intermediates and inactivates fumarate reductase, phosphate acetyltransferase, alcohol/acetaldehyde dehydrogenase, and D-lactate dehydrogenase [28]. Thirty-two grams per liter of D-lactate ( $99.9 \%$ chiral purity) could be produced from $40 \mathrm{~g} / \mathrm{L}$ of glycerol ( 0.82 mole lactate per mole of consumed glycerol, $1.5 \mathrm{~g} / \mathrm{L} / \mathrm{h}$ productivity). This strain was also tested for the ability to utilize waste glycerol as a substrate, and a higher yield was observed $(0.87$ mole lactate per mole of consumed glycerol) with the final concentration of D-lactic acid of $34 \mathrm{~g} / \mathrm{L}$ [28]. Furthermore, an L-specific LDH from Streptococcus bovis was able to be introduced to replace the native E. coli D-specific LDH from the previous study. Fifty grams per liter of L-lactic acid $(99.9 \%$ chiral purity) was produced from $56 \mathrm{~g} / \mathrm{L}$ of waste glycerol with a yield of $0.91 \mathrm{~mol} / \mathrm{mol}$ glycerol. Other than engineered strains, lactic acid production was also observed in glycerol fermentation by E. coli AC-521, a wild-type soil bacterium [27]. The yield reached 0.9 mole lactic acid per mole consumed glycerol with a final concentration of about $85.8 \mathrm{~g} / \mathrm{L}(0.97 \mathrm{~g} / \mathrm{L} / \mathrm{h}$ productivity), however no data about chiral purity was presented in this study.

A 1,2-PDO-dependent glycerol fermentation capability has been discovered in some E. coli strains $[18,22]$. 1,2-PDO is a chemical that can serve as a building block for polyesters, anti-freeze agents, or solvents [85], and is currently priced around $\$ 1.08$ to $\$ 1.59$ per kg with an estimated global demand around 1.36 billion kilogram per year [86]. To enhance natural production of 1,2-PDO, an engineered $E$. coli was constructed by disrupting acetate and lactate synthesis and replacing the native PEP-dependent dihydroxyacetone kinase with an ATP-dependent dihydroxyacetone kinase from Citrobacter freundii. This causes the overexpressing enzymes responsible for the reductive 1,2-PDO pathway, and results in a strain that can produce $5.6 \mathrm{~g} / \mathrm{L}$ of 1,2-PDO from the fermentation of glycerol with a yield of $0.26 \mathrm{~mol} / \mathrm{mol}$ glycerol [30].

E. coli has also been genetically modified to generate desired products that are not naturally produced from glycerol by E. coli such as 1,3-PDO and succinate [6]. 1,3-PDO is a building block of biodegradable plastic polytrimethyleneterephthalate (PTT) and also a valuable product with various uses (resins, coolants, mortars and inks). A recombinant strain of E. coli was constructed by transferring the $\mathrm{B}_{12}$-independent glycerol dehydratase DhaBl and its activating factor DhaB2 from Clostridium butyrium. The final concentration, yield and overall productivity of 1,3-PDO was $104.4 \mathrm{~g} / \mathrm{L}$, $1.09 \mathrm{~mol} / \mathrm{mol}$ and $2.61 \mathrm{~g} / \mathrm{L} / \mathrm{h}$, respectively [31]. Another product capable of being produced by recombinant E.coli.is succinate. Succinate is one of the top twelve building block chemicals according to the U.S. Department of Energy and is typically used for creating biodegradable plastic polybutylene succinate [87]. Current glucose to succinic acid commercial production techniques are relatively sophisticated, and are capable of producing a succinic acid yield about $1.45 \mathrm{~mol} / \mathrm{mol}$ glucose [88]. 
However, using glycerol as a substrate has advantages such as the low cost of the feedstock and higher yield of succinic acid (on an equal 3-carbon basis) [17]. A comparable yield (0.8 mol/mol glycerol) of succinic acid production was achieved in the recombinant $E$. coli, although the final concentration was low (12 g/L) [32]. To construct this strain, phosphoenolpyruvate carboxykinase (PEPCK) was upregulated, and genes responsible for ethanol and formate formation were deleted.

\subsubsection{Klebsiella Species}

As another member in the Enterobacteriaceae family, Klebsiella is considered one of the most promising candidates for producing 1,3-PDO from glycerol [34] and over the past few years a large amount of Klebsiella research has been focused on enhancing the production of 1,3-PDO production during the fermentation of waste glycerol. Pilot scale studies as large as $5000 \mathrm{~L}$ have been launched in order to test Klebsiella's potential for industrial application [34]. Syntheses of other products, like 2,3-butanediol (2,3-BD) and ethanol have also been reported in considerable amounts [37,38].

To increase the production of 1,3-PDO through the fermentation of glycerol by Klebsiella species, genetic enhancements were employed with different strategies such as minimizing undesired byproducts or increasing the utilization of glycerol. The formation of lactate and ethanol compete with the formation of 1,3-PDO through the consumption of reducing equivalents, and often impose difficulties on the downstream processes responsible for the purification and recovery of 1,3-PDO [35,36]. By creating a lactate deficient mutant (LDH3) from $K$. oxytoca M5a1, the productivity and yield of 1,3-PDO were increased from 0.63 to $0.83 \mathrm{~g} / \mathrm{L} / \mathrm{h}$ to 0.41 to $0.53 \mathrm{~mol} / \mathrm{mol}$ glycerol, respectively [35]. By inactivating aldehyde dehydrogenase $(\mathrm{ADH})$, the enzyme responsible for ethanol formation in K. pneumoniae YMU2, less ethanol was produced in the broth (from $9.26 \mathrm{~g} / \mathrm{L}$ to $1.70 \mathrm{~g} / \mathrm{L}$ ) with a higher productivity (from $0.81 \mathrm{~g} / \mathrm{L} / \mathrm{h}$ to $1.07 \mathrm{~g} / \mathrm{L} / \mathrm{h}$ ) and yield (from $0.36 \mathrm{~mol} / \mathrm{mol}$ to $0.70 \mathrm{~mol} / \mathrm{mol}$ ) of 1,3-PDO observed [36]. To enhance both glycerol oxidative and reductive metabolisms, formate dehydrogenase (FDH) from Candida boidinii was expressed in K. oxytoca YMU1 [89]. The subsequent yield of 1,3-PDO increased about $17.3 \%$, from 0.39 to $0.45 \mathrm{~mol} / \mathrm{mol}$ glycerol.

Other value-added chemicals can also be produced through glycerol fermentation by Klebsiella species. For example, 2,3-BD was found to be the major product of fermentation by K. pneumonia G31 under microaerobic conditions with an initial alkaline $\mathrm{pH}$ [37]. 2,3-BD is a high-value chemical that can serve as a precursor for chemical products like methyl ethyl ketone, $\gamma$-butyrolactone, and 1,3-butadiene [90]. The final concentration of 2,3-BD reached $49.2 \mathrm{~g} / \mathrm{L}$ after $280 \mathrm{~h}$ of fermentation (a productivity of $0.18 \mathrm{~g} / \mathrm{L} / \mathrm{h}$ ) and the overall yield was $0.36 \mathrm{~mol} / \mathrm{mol}$ glycerol. An engineered strain of $K$. pneumonia can produce ethanol when the lactate dehydrogenase was inactivated and pyruvate decarboxylase along with aldehyde dehydrogenase from Zymomonas mobilis were introduced. Compared to the wild type strain, final concentration, yield, and productivity were improved from $21.5 \mathrm{~g} / \mathrm{L}$ to $31.0 \mathrm{~g} / \mathrm{L}, 0.62 \mathrm{~mol} / \mathrm{mol}$ glycerol to $0.89 \mathrm{~mol} / \mathrm{mol}$ glycerol, and $0.93 \mathrm{~g} / \mathrm{L} / \mathrm{h}$ to $1.2 \mathrm{~g} / \mathrm{L} / \mathrm{h}$, respectively [38].

\subsubsection{Citrobacter Species}

Citrobacter species are well-known for their ability to produce 1,3-PDO from fermenting glycerol. Studies using chemical grade glycerol in the mid-90s had revealed that the final concentration of 
1,3-PDO produced by $C$. freundii to be comparable to those produced by Klebsiella and Clostridium species, although the reaction rate is much slower [91]. Recent studies have shown that both wild-type and engineered Citrobacter species are capable of using pretreated biodiesel waste glycerol as a substrate to produce various value-added products. For example, C. freundii strain (FMCC-B 294) can ferment pretreated waste glycerol to produce 1,3-PDO in fed-batch fermentation achieving final concentration of $68.1 \mathrm{~g} / \mathrm{L}$ with yield of $0.48 \mathrm{~mol} / \mathrm{mol}$ and volumetric productivity of $0.79 \mathrm{~g} / \mathrm{L} / \mathrm{h} \mathrm{[39]}$. This strain can also endure non-sterile feeding, which may reduce the energy requirement for pretreatment. Other than C. freundii, C. werkmanii DSM 17579 is another potential strain for 1,3-PDO production. The highest achieved yield per mole of glycerol consumed and productivity in fed-batch fermentation was $0.62 \mathrm{~mol} / \mathrm{mol}$ and $2.84 \mathrm{~g} / \mathrm{L} / \mathrm{h}$, respectively [40]. However, the highest yield, productivity, and final concentration of 1,3-PDO achieved by $C$. freundii was lower than those achieved by Clostridium species. Besides PDO, C. freundii $\mathrm{H} 3$ can ferment chemical grade glycerol to produce $\mathrm{H}_{2}$ with a yield of $0.94 \mathrm{~mol} / \mathrm{mol}$ [41]. A recombinant of $C$. freundii aimed at producing violacein was examined for its ability to ferment glycerol as substrate. Violacein is a blue-purple bacterial pigment that has antibacterial, antioxidant, antiviral, and anti-protozoal properties [92]. The maximum final concentration and productivity were $4.13 \mathrm{~g} / \mathrm{L}$ and $82.6 \mathrm{mg} / \mathrm{L} / \mathrm{h}$, respectively [42].

\subsection{Clostridium Species}

Similar to Klebsiella, the glycerol fermenting ability of Clostridium species has been extensively studied with the goal of enhancing the production of 1,3-PDO [93]. The value-added product butanol was also discovered during fermentation.

The possible effects of dilution rate and substrate concentration on glycerol fermentation of C. butyricum VPI 3266 were examined [43]. The highest productivity of 1,3-PDO (10.3 g/L/h) was achieved under the dilution rate $0.30 \mathrm{~h}^{-1}$ and at substrate concentration of $60 \mathrm{~g} / \mathrm{L}$. The yield was around $0.65 \mathrm{~mol} / \mathrm{mol}$. Glycerol fermentation of C. butyricum AKR102a in an automatic fed-batch reactor can produce $93.7 \mathrm{~g} / \mathrm{L}(3.3 \mathrm{~g} / \mathrm{L} / \mathrm{h})$ 1,3-PDO from pure glycerol and $76.2 \mathrm{~g} / \mathrm{L}$ from pretreated waste glycerol $(2.3 \mathrm{~g} / \mathrm{L} / \mathrm{h})$ [44]. C. butyrium VPI 1718 was tested for production of 1,3-PDO from non-sterile waste glycerol and was found to produce 1,3-PDO with a final concentration of $67.9 \mathrm{~g} / \mathrm{L}$, and yield of $0.67 \mathrm{~mol} / \mathrm{mol}$ glycerol [45]. An engineered strain was constructed by introducing the reductive pathway of $C$. butyricum to $C$. acetobutylicum [46]. This recombinant, DG1(pSPD5), was capable of fermenting glycerol with a 1,3-PDO productivity of $3 \mathrm{~g} / \mathrm{L} / \mathrm{h}$ and a yield of $0.66 \mathrm{~mol} / \mathrm{mol}$ glycerol.

Other than 1,3-PDO, butanol can also be produced through the fermentation of glycerol by Clostridium [47]. Butanol is a chemical that can be applied as a chemical synthesis building block, solvent, or as a potential biofuel. Microbial production of butanol lost its primary advantage in the 1960s due to the increasing cost of suitable substrates [94], but with the current low price of biodiesel waste glycerol combined with advances in genetic engineering techniques this alternative pathway may now become commercially practical. The simultaneous production of 1,3-PDO and butanol was reported in C. pasteurianam (ATCC 6013) by feeding pretreated waste glycerol with productivities of $0.42 \mathrm{~g} / \mathrm{L} / \mathrm{h}(0.17 \mathrm{~mol} / \mathrm{mol})$ and $2.49 \mathrm{~g} / \mathrm{L} / \mathrm{h}(0.28 \mathrm{~mol} / \mathrm{mol})$, respectively [48]. 


\subsection{Propionibacterium Species}

Fermentative glycerol dissimilation in Propionibacteria strains has been investigated for the production of propionic acid and trehalose $[4,17]$. As an important intermediate for cellulose fibers, herbicides and perfumes, large quantities of propionic acid are produced by chemical synthesis, e.g., oxidation of propionaldehyde with air and the catalytic dehydration of glycerol $[49,95,96]$. One of the best natural producers of propionate from glycerol is Propionibacterium acidipropionici, capable of achieving a final concentration of $42 \mathrm{~g} / \mathrm{L}$ propionate with an overall yield of $0.84 \mathrm{~mol} / \mathrm{mol}$ of glycerol consumed and a productivity of $0.36 \mathrm{~g} / \mathrm{L} / \mathrm{h}$ using technical grade glycerol [17]. A knockout mutant strain of $P$. acidipropionici lacking acetate kinase (ACK) was studied for its ability to use glycerol as sole carbon source during fermentation [49]. The final concentration of propionate (106 g/L) from the fermentation of glycerol was much higher than wild type $(42 \mathrm{~g} / \mathrm{L})$. The yield and productivity, however, were lower than wild type $(0.66 \mathrm{~mol} / \mathrm{mol}$ consumed glycerol and $0.10 \mathrm{~g} / \mathrm{L} / \mathrm{h})$. When pretreated waste glycerol was used as carbon source, this mutant strain achieved a higher yield of propionate $(0.88 \mathrm{~mol} / \mathrm{mol}$ glycerol $)$ and a slightly lower productivity $(0.09 \mathrm{~g} / \mathrm{L} / \mathrm{h})$.

Trehalose can also accumulate in the biomass of some Propionibacteria strains during glycerol fermentation. Trehalose is a non-reducing sugar that can protect bacterial cells against osmotic stress and has value in the food and cosmetic industries as well as clinical applications [97]. Although enzymatic transformations have been reported as a viable method for trehalose production [98], accumulation of trehalose in microbial biomass is considered a less expensive method when a cheap carbon source is used [93]. Wild type and osmotic sensitive mutants of P. freudenreichi subsp. Shermanii were analyzed for the production of trehalose from waste glycerol [50]. The final concentration of trehalose was higher in the mutant strain than in wild type $(678 \mathrm{mg} / \mathrm{L}$ to $158 \mathrm{mg} / \mathrm{L})$. The use of waste glycerol further increased the final concentration of trehalose from $678 \mathrm{mg} / \mathrm{L}$ to $1303 \mathrm{mg} / \mathrm{L}$ in the mutant strain. It was possible that impurities in waste glycerol positively influenced trehalose accumulation by creating stressful conditions that signal the bacterial cells to accumulate trehalose [50].

\subsection{Other Bacterial Species and Mixed Culture}

Pure bacterial species and mixed culture communities outside of Enterobacteriaceae, Clostridia, and Propionibacterium species have also been investigated for their abilities to convert waste glycerol into value-added products like hydrogen, 1,3-PDO, probiotic biomass, and polyhydroxyalkanoates (PHAs). For example, Rhodopseudomonas palustris CGA009, a purple non-sulfur photosynthetic bacterium, has been demonstrated to have the ability to photo-ferment pretreated waste glycerol to hydrogen [51], a clean and efficient energy carrier that has received enormous attention. As previously described, glycerol fermentation theoretically produces more $\mathrm{NADH}$ than glucose fermentation on a 3 -carbon basis, and thus has higher potential to generate hydrogen gas (one mole of $\mathrm{H}_{2}$ per mole of excess NADH) [12,13]. Gene deletion experiments have indicated that hydrogen production in $R$. palustris is mainly due to nitrogenase, which catalyzes proton reduction in the absence of nitrogen gas. The yields of hydrogen were $6 \mathrm{~mol} / \mathrm{mol}$ using pure glycerol and $4 \mathrm{~mol} / \mathrm{mol}$ using waste glycerol. Some strains of Paenibacillus macerans were also reported to grow efficiently on glycerol as sole carbon 
source, but hydrogen yield $(0.80 \mathrm{~mol} / \mathrm{mol}$ glycerol) was much lower than that by $R$. palustris CGA009 [52]. Ethanol was the dominant liquid product while 1,2-PDO and acetone were also detected [52]. Mixed cultures have also been investigated for potential hydrogen production from waste glycerol. The estimated maximum hydrogen yields ranged from 0.8 to $0.96 \mathrm{~mol} / \mathrm{mol}$, which is comparable to the hydrogen yield with glucose as substrate on a 3-carbon basis [54,55]. Thermophilic mixed cultures were also studied for their potential ultilization of waste glycerol to produce hydrogen [53]. Although the yield $(0.30 \mathrm{~mol} / \mathrm{mol}$ glycerol $)$ was not as favorable, thermophilic mixed culture fermentation might provide several advantages over mesophilic mixed culture fermentation, such as more effective pathogen control and lower risk of methanogen contamination $[53,99,100]$.

As one of the natural producers of 1,3-PDO, Lactobacillus diolivorans has the potential to produce 1,3-PDO from glycerol. The highest final concentration produced was $73.7 \mathrm{~g} / \mathrm{L}$ under fed-batch cultivation [101]. A recent study suggests that biodiesel waste glycerol can support cell growth of L. acidophilus, L. delbrueckii, and L. plantarum, with resulting probiotic cell mass obtained as a value-added product.

PHAs are typically stored by bacteria as a carbon source and energy reserve [102]. This chemical can also serve as an alternative to biodegradable polymers. Bacterial synthesis of PHAs is a cheaper way to produce this expensive compound compared to chemical synthesis techniques. Cupriavidus necator DSM 545 has demonstrated the capability to accumulate poly(3-hydroxybutyrate), a polyhydroxyalkanoate (PHA), in its cell mass by assimilating either pure glycerol or waste glycerol, with higher productivities able to be achieved using waste glycerol versus pure glycerol [57]. Zobellella denitrificans MW1 was also reported to use glycerol as sole substrate to accumulate poly(3-hydroxybutyrate) in its cell mass [58]. The highest yield was achieved using $10 \mathrm{~g} / \mathrm{L}$ of glycerol $(0.31 \mathrm{~g} / \mathrm{g}$ glycerol, $80.4 \%$ of the cell dry weight). A waste glycerol supplement can increase the biomass production up to 1.7 fold and PHA accumulation up to 2.2 fold in Pseudomonas putida GO16 $(0.11 \mathrm{~g} / \mathrm{L} / \mathrm{h})$, compared to growth on sodium terephthalate (major plastic waste from pyrolysis of Polyethylene terephthalate) alone [59].

\subsection{Microbial Conversion of Glycerol by Yeast}

Glycerol is one of the byproducts of sugar fermentation in yeast, acting as an osmotic regulator and a way to balance excess reducing equivalent [103]. The glycerol transportation and dissimilation pathways of yeast have been intensively studied since the 1960s (Figure 3) [104-108]. A proton symport protein encoded by the STL1 gene in both Saccaromyces cerevisiae and Candida alba is responsible for glycerol active transportation through the cell membrane [109,110]. However, simple diffusion was also observed in S. cerevisiae [107]. GUP1, a member of membrane-bound O-acyltransferases, has been indicated to involve extracellular glycerol transportation, and thus could also be one of the membrane-bound proteins that are responsible for the active uptake of glycerol via the proton symport system. After entering the cell membrane, glycerol is then phosphorlyated by glycerol kinase (glyK) to become glycerol-3-phosphate, a glycolytic intermediate that can be dehydrogenated in the mitochondria by glycerolphosphate oxidase (gpO) to form dyhydroxyacetone phosphate (DHAP) [107]. In another species of yeast, Schizosaccharomyces pombe, intracellular glycerol is directly oxidized by a $\mathrm{NAD}^{+}$-dependent dehydrogenase to DHA. DHA is subsequently phosphorylated to DHAP after 
which it may enter glycolysis. Glycolysis produces acetyl-CoA, one of the major building blocks to both TCA cycle and fatty acid synthesis, which is capable of subsequently generating valuable products like citric acid and glycolipids.

Figure 3. Eukaryotic pathway of glycerol utilization. Enzymes: glyK, glycerol kinase; glyP, glycerophosphatase; gpO, glycerophosphate oxidase; g3pD, glycerol-3-phosphate dehydrogenase. Chemical intermediates and products: DHA, dihydroxyacetone; DHAP, dihydroxyacetone phosphate; L-G3P, L-glycerophosphate. (Dash line indicates reactions in Schizosaccharomyces pombe; filled box indicates potential products).

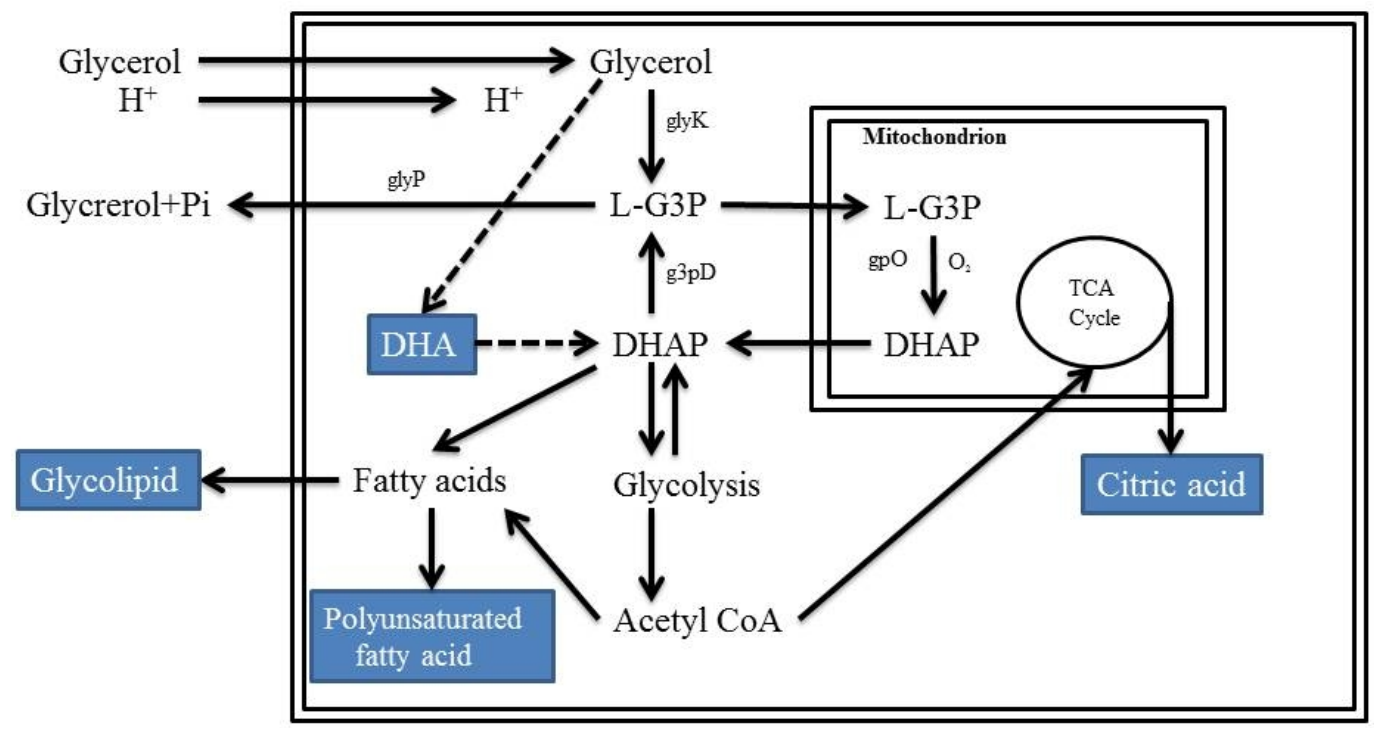

Yeast species have been screened and investigated for their potential in converting waste glycerol to various products such as citric acid, biosurfactants, single cell oil (SCO), and carotenoids [111]. Additionally, products like ethanol and 1,2-PDO can also be produced by genetically engineered S. cerevisiae strains.

Citric acid is a flavoring additive and preservative agent in the food industry with a current estimated annual production of more than 800,000 tons which is expected to continue to increase by $5 \%$ per year [111-113]. Citric acid production from the submerged fermentation of Aspergillus niger (fungus) using sugar as substrate is a well-developed technique. However, feeding glycerol to $A$. niger does not favor citric acid production [114]. As an alternative to A. niger, Yarrowia lipolytica was investigated for citric acid production using glycerol as substrate [15]. Under optimal conditions, Y. lipolytica NCIM 3589 has shown the ability to yield a final citric acid concentration of $77.4 \mathrm{~g} / \mathrm{L}$, which is comparable to the final concentration obtained by A. niger [60]. Among all the strains tested, Y. lipolytica Wratislavia AWG7 produced an even higher citric acid concentration of $139 \mathrm{~g} / \mathrm{L}$ after $120 \mathrm{~h}$ with an initial glycerol concentration of $200 \mathrm{~g} / \mathrm{L}$ [61].

Glycolipids like sophorolipid and mannosylerythritol can be categorized as biosurfactants, which are a series of microbial produced molecules that have similar structures and chemical properties to surfactants [115]. Compared to other surfactants, biosurfactants contain advantages such as low toxicity and biodegradability, making them environmentally friendly for remediation processes in both liquid and on solid surfaces [116,117]. The production of biosurfactants was previously believed to 
only be performed by bacterial species such as the rhamnolipid-producing Pseudomonas aeruginosa, but recent discoveries have shown similar levels of glycolipid production in Candida and Pseudozyma [115,118]. Candida bombicola ATCC 22214 has been proven to produce sophorolipids by fermenting biodiesel waste glycerol with a final concentration of about $60 \mathrm{~g} / \mathrm{L}$ [62]. It has also been reported that Pseudozyma antarctica JCM 10317 was able to produce $16.3 \mathrm{~g} / \mathrm{L}$ mannosylerythritol lipids from $100 \mathrm{~g} / \mathrm{L}$ glycerol supplied with $2 \%$ mannose [63].

The oleaginous yeast Cryptococcus curvatus has the ability to grow on crude glycerol. Microbial lipophilic contents, often known as SCOs, contain multiple useful polyunsaturated fatty acids that have potential in both the medical and dietetic fields [119] in additional to potential use as a feedstock for second generation biodiesel production [69,111]. A fed-batch culture of C. curvatus was able to produce $32.9 \mathrm{~g} / \mathrm{L}$ of biomass with a $52 \%$ lipid content within 12 days [64]. Rhodotorula glutinis is also oleaginous yeast that is able to grow on a mixture of crude glycerol and the thin stillage fraction from brewery waste to produce $14.8 \mathrm{~g}$ biomass per liter (36.50\% lipid content) [65].

The value of carotenoids, a group of pigments, has increased along with the demand for use as a cosmetic additive and food colorant [14,120]. Yeast species Sporobolomyces ruberrimus CBS 2636 has recently been investigated for its potential to produce carotenoid using industrial glycerol from the soap manufacturing process as one of the co-substrates $[14,66]$. The maximum concentration that could be achieved was $3425.9 \mu \mathrm{g} / \mathrm{L}$ with a carotenoid productivity of $56.9 \mu \mathrm{g} / \mathrm{L} / \mathrm{h}(41.9 \mu \mathrm{g} / \mathrm{g}$ glycerol).

$S$. cerevisiae can also be genetically engineered to produce some other products from glycerol fermentation, which are either not naturally produced or present in low concentrations, such as ethanol and 1,2-PDO. S. cerevisiae is an excellent ethanol producer when using sugar substrates. However, fermenting a more reduced substrate like glycerol to ethanol might require additional metabolic routes to handle the excess reducing equivalents. Simultaneous overexpression of glycerol dehydrogenase $(G c y)$ and dihydroxyacetone kinase (Dak) in S. cerevisiae was investigated for ethanol production by fermenting glycerol [67]. The final ethanol concentration was $1.66 \mathrm{~g} / \mathrm{L}, 2.4$ times greater than the wild type $(0.69 \mathrm{~g} / \mathrm{L})$. The concentration was further increased to $2.4 \mathrm{~g} / \mathrm{L}$ (3.4 fold improvement over the wild type) by overexpression of glycerol uptake protein GUP1. 1,2-PDO is not naturally produced by $S$. cerevisiae, yet recombinant strains of $S$. cerevisiae 499 were constructed to produce 1,2-PDO by fermenting glycerol [68]. A 1,2-PDO final concentration of $2.19 \mathrm{~g} / \mathrm{L}$ with a yield of $0.258 \mathrm{~mol} / \mathrm{mol}$ glycerol was achieved in strain $S$. cerevisiae 499 sJDPMG. This recombinant overexpressed glycerol dehydrogenase $(g d h)$ and GUP1 protein, along with the expressing methylglyoxal synthase (mgs) and glycerol dehydrogenase ( $g l d A)$ from E. coli.

\subsection{Microbial Conversion of Glycerol by Fungi}

Microbial conversion of waste glycerol by fungi is another possible approach to generate value-added products, such as SCO, eicosapentanoic acid (EPA), and $\beta$-carotene, as studies have shown that fungi tend to accumulate lipids inside their mycelia [71]. Lentinula edodes strains AMRL 119 and AMRL 121 can produce a maximum of $5.2 \mathrm{~g} / \mathrm{L}$ of biomass and a yield of $0.1 \mathrm{~g} / \mathrm{g}$ biomass of lipid (mostly linoleic acid) under carbon limitation [69]. A. niger strains NRRL 364 and LFMB 1 were tested under nitrogen limiting conditions, resulting in $20.5-21.5 \mathrm{~g} / \mathrm{L}$ of oxalic acid production and $3.1-3.5 \mathrm{~g} / \mathrm{L}$ of lipids with a yield of $0.41-0.57 \mathrm{~g} / \mathrm{g}$ of biomass (composed by oleic acid and linoleic acid). Galactomyces geotrichum 
is an ascomycetous fungus that has the ability to use glycerol and FFA within waste glycerol to produce 0.44 grams of lipid per gram biomass [70]. In addition to the fungi previously mentioned Thamnidium elegans has been shown to be able to produce up to $11.6 \mathrm{~g} / \mathrm{L}$ of oil, corresponding to $71.1 \% \mathrm{wt} / \mathrm{wt}$ of oil in biomass [71].

As a specific member of microbial lipohilic content, EPA is an important member in omega-3 polyunsaturated fatty acid (PUFA) family, and has medical applications for treating cardiovascular disease, cancer and Alzheimer's disease [72,121,122]. PUFA is an important part of the human diet, with most dietary PUFA extracted from fish [123]. However, fish extracted PUFAs contain undesired odors and accumulated harmful heavy pollutants. Microalgae accumulation of PUFAs was evaluated as a commercial replacement for fish oil [123,124], but microalgae accumulation of EPA is often considered to be less efficient [72]. The fungus Pythium irregulare was capable of producing EPA from waste glycerol with a final concentration of $90 \mathrm{mg} / \mathrm{L}$ and a productivity of $14.9 \mathrm{mg} / \mathrm{L} /$ day [72] Results from this study also suggest that impurities within waste glycerol like soap and methanol can inhibit cell growth, and thus should be removed by pretreatment.

A nutritional supplement, $\beta$-carotene, can be accumulated in the cell mass of Blakeslea trispora during grow on waste glycerol media. The highest concentration obtained was $15 \mathrm{mg} \beta$-carotene per gram of cell mass by using $60 \mathrm{~g} / \mathrm{L}$ waste glycerol [73]. Impurities within waste glycerol did not inhibit the cell growth, but actually stimulated $\beta$-carotene synthesis.

\subsection{Glycerol as Carbon Source for Microalgae Species}

Being a potential biorefinery feedstock, microalgae species have raised considerable research interest [125] and accordingly waste glycerol has been studied as a possible cheap carbon source for growing microalgae biomass. Though glycerol can be metabolized by several microalgae species, even in the absence of carbon dioxide [126-128], the metabolic pathway of glycerol in microalgae has not been well developed. It is possible that in two of the Mycobacterium species, glycerol is first phosphorylated and then oxidized to triose phosphate [128]. Triose phosphate then goes through a stepwise oxidation and becomes pyruvate to enter TCA cycle. Therefore, triose phosphate might be one of the key intermediates for which oxygen is required. The alga species Schizochytrium limacinum SR21 can accumulate docosahexaenoic acid (DHA) in its cell mass, with DHA productivity of $0.51 \mathrm{~g} / \mathrm{L} /$ day using waste glycerol as substrate [74]. DHA is an important omega-3 polyunsaturated fatty acid with research suggesting a role in preventing cardiovascular disease [74].

\subsection{Converting Glycerol to Value-Added Products Using Fermentation, Co-Digestion, and} Microbial Electrochemical Technologies

\subsubsection{Fermentation}

Generally speaking, fermentation processes can be operated in batch, fed-batch, and continuous modes [129]. In terms of glycerol microbial conversion, batch and fed-batch cultures were often employed because value-added metabolites and biomass can accumulate in relatively high final concentrations compared to continuous culture. For example, 67.9-104.4 g/L of 1,3-PDO can be produced by batch and fed-batch cultures $[31,39,44,45]$, which are higher than concentrations achieved 
in continuous culture (35.2-48.5 g/L) [130]. However, compounds other than the desired products also accumulate during the conversion process which might lead to inefficiencies due to inhibitory effects. On the other hand, continuous cultures can regulate accumulation by adjusting dilution rate, and thus have relatively high productivities. For example, $4.9-8.8 \mathrm{~g} / \mathrm{L} / \mathrm{h}$ of 1,3-PDO can be produced under low dilution rates [130]. Although low final concentrations often accompany continuous cultures, which might hinder downstream processes such as separation and purification [130].

Process-based enhancements like cell immobilization or co-digestion are often applied to these cultivation processes to improve glycerol utilization or metabolite production. Benefits conferred by cell immobilization might include increased stability in unfavorable environmental conditions during operation as well as avoiding washout [33,131,132]. For example, with microencapsulation, the biomass of K. pneumoniae was increased 2.6-fold compared to free cell cultures [33]. As the result, the final concentration of 1,3-PDO obtained in batch cultures was $63.1 \mathrm{~g} / \mathrm{L}$ with a yield of $0.65 \mathrm{~mol} / \mathrm{mol}$ glycerol. In continuous culture, the overall productivity of 1,3-PDO was $4.46 \mathrm{~g} / \mathrm{L} / \mathrm{h}$ with a yield of $0.43 \mathrm{~mol} / \mathrm{mol}$ glycerol. By immobilizing C. pasteurianam cells on Amberlite, the maximum $n$-butanol yield of $0.43 \mathrm{~mol} / \mathrm{mol}$ glycerol could be produced [47].

\subsubsection{Anaerobic Co-Digestion}

Anaerobic co-digestion of glycerol has been investigated to increase biogas productivity. Preceded by a mixed bacterial culture, this process consists of anaerobic digestion with waste glycerol as a complementary substrate to balance the $\mathrm{C} / \mathrm{N}$ ratio [133]. As the result of co-digestion, useful products like biogas (consisting mainly $\mathrm{CH}_{4}$ and $\mathrm{CO}_{2}$ ) are produced. Direct utilization of waste glycerol without pretreatment could be problematic to microbes because of its alkalinity and high salt levels [134]. The application of pretreated waste glycerol has been reported as a positive supplement to increase the productivity of anaerobic digestion. For example, the methane production rate of a mixture of olive mill wastewater and slaughterhouse wastewater was increased from $479 \mathrm{~mL} / \mathrm{d}$ to $1210 \mathrm{~mL} / \mathrm{d}$ by volumetrically adding $1 \%$ waste glycerol as supplement [56]. Compared to mono-digestion, biogas production was also increased by about $400 \%$ under mesophilic conditions when pig manure was co-digested with $4 \%$ waste glycerol [135].

\subsubsection{Microbial Electrochemical Conversion}

Microbial electrochemical technologies (METs) can recover electrons from glycerol as electrical current using a microbial fuel cell (MFC) (Figure 4a) [136] or produce hydrogen using a microbial electrolysis cell (MEC) (Figure 4b) [137]. METs may contain either a mixed bacterial culture or pure culture that grows on the anode surface or in anodic chamber carrying out the oxidation of organic matter. During oxidation, electrons are released and then transferred to the anode through direct contact, electron shuttles, or conductive nanowires [136,138-141]. In an MFC, external electron acceptors (like oxygen or ferric cyanide) have to be fixed in order to create a potential difference large enough to allow current flow [142]. However, in an MEC, no external electron acceptor is added as the reduction of hydrogen ions on the cathode surface has a more negative redox potential than the anode, and thus an additional voltage must be applied to generate the current flow [143]. 
Figure 4. Single-Chamber microbial electrolysis cell (a) Single-Chamber microbial electrolysis cell (b) (adapted from [143]).

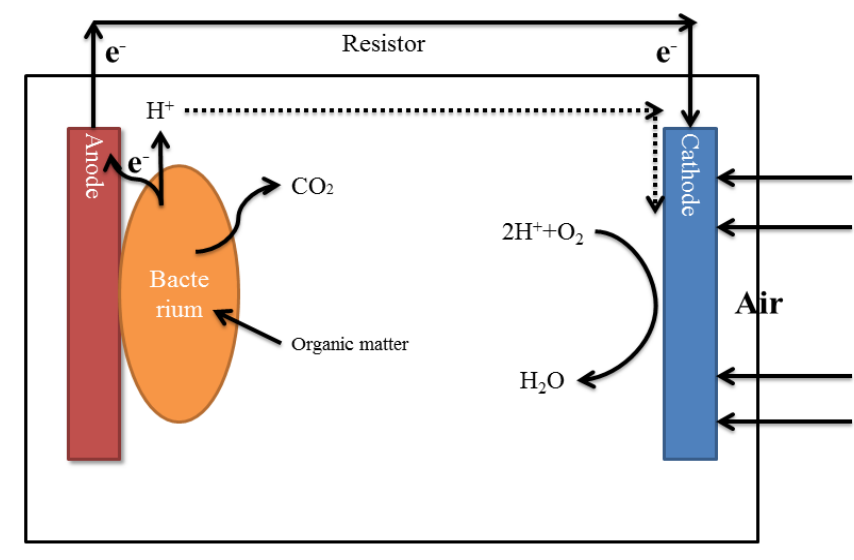

(a)

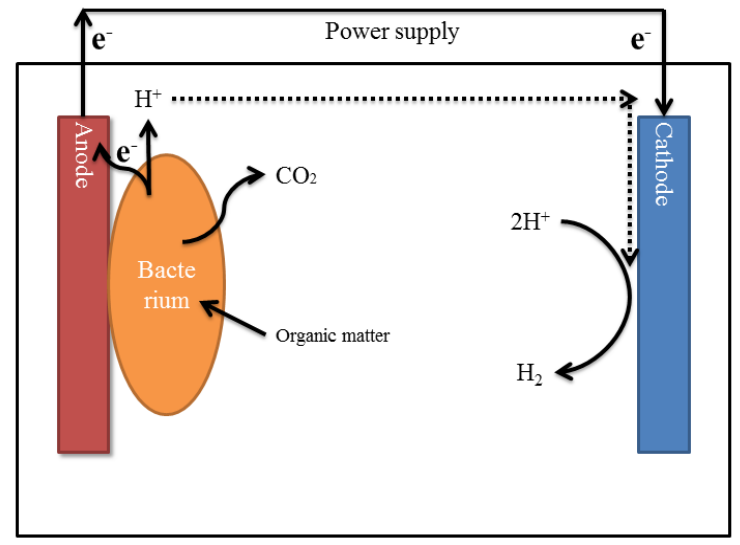

(b)

Both pure and mixed culture MFCs from which electrical power can be generated using glycerol are currently being investigated as an alternative method of biodiesel waste glycerol conversion. Enhancements have been made based on the selection of a favorable microbial consortia as well as improvements to MFC designs. Electrical power at a maximum density of $600 \mathrm{~mW} / \mathrm{m}^{2}$ can be generated from pure glycerol using a pure culture of Bacillus subtilis in a single chamber MFC with air cathode [75]. Although some pure bacterial strains, such as Geobacter sulfurreducens, have the ability to produce comparable power to mixed culture communities using defined substrates such as acetate [144], the use of mixed cultures in MFCs has the advantage of increased stability and a wider range of substrates capable of being utilized [145]. Electrical power can be directly generated from waste glycerol using a single chamber MFC with a mixed microbial consortium enriched from domestic wastewater [76]. The maximum power density generated from waste glycerol was $487 \mathrm{~mW} / \mathrm{m}^{2}$ with carbon cloth anode, but was further increased to $2110 \mathrm{~mW} / \mathrm{m}^{2}$ with a heat-treated carbon brush anode. An MFC with graphite fiber brush anodes can produce electrical current at power densities of $4.6 \mathrm{~W} / \mathrm{m}^{3}$ using pure glycerol and $2.3 \mathrm{~W} / \mathrm{m}^{3}$ using waste glycerol [77].

A recent study suggests that by externally applying current to a glycerol fermentation reactor inoculated with a mixed culture, metabolite formation can be significantly influenced with associated increases of highly reduced chemicals such as propanol and valerate [146]. Although the mechanism behind this metabolic shift was not clear, it is possibly related to the high hydrogen partial pressure caused by the current supplied in the vicinity of cathode. Besides producing more reduced, value-added products, attempts have also been made to achieve high levels of hydrogen production in pure and mixed culture MECs using glycerol as a substrate. Simultaneous production of hydrogen and ethanol from pretreated waste glycerol was reported in a two compartment MEC inoculated with Enterobacter aerogenes NBRC 12010 [69]. The yield of hydrogen and ethanol were 0.74 and $0.92 \mathrm{~mol} / \mathrm{mol}$ glycerol respectively. The consumption of glycerol can be increased from $45.7 \%$ to $84.5 \%$ through the application of a potential of $0.2 \mathrm{~V}$. Mixed culture MECs with a single chamber design can produce hydrogen yields of $3.9 \mathrm{~mol} / \mathrm{mol}$ and $5.4 \mathrm{~mol} / \mathrm{mol}$ glycerol, higher than pure culture MECs, with applied voltages of 0.9 and $1.0 \mathrm{~V}[79,80]$. The application of pretreatments like heat shock should be considered to before inoculation as a method to prevent growth of methanogens. 


\section{Outlook}

As previously discussed, the production of biodiesel waste will continue to increase with the growth of the biofuel market. The surplus of glycerol is not only creating difficulties for the glycerol production industry but also for biodiesel plants. Microbial conversion is an efficient and sustainable method for converting waste glycerol that avoids the disadvantages of direct application and chemical transformation, such as the inability to use waste glycerol directly and low product specificity [6]. Although there are still hurdles involved in constructing a suitable industrial scale reactor to more accurately predict real production costs, encouraging results have been demonstrated (Table 1).

1,3-Propanediol is one of the various value-added products that can be generated from glycerol fermentation, and is, a chemical that is already produced nationally on a level of about 31.6 million $\mathrm{kg}$ per year, and appears to be an encouraging target for future waste glycerol microbial conversion efforts [147,148]. Currently, commercial synthesis of 1,3-PDO is performed either by petroleum chemicals (acrolein and ethylene) [147,148] or by glucose fermentation of engineered bacterial strains [24,149]. As natural producers of 1,3-PDO, members of the Klebsiella, Citrobacter, and Clostridium families have been intensively studied for potential industrial applications. Compared to these bacteria, E. coli has an advantage being a highly tractable, and thus easier to be manipulated for various industrial needs [31]. In fact, one of the highest 1,3-PDO concentrations achieved by glycerol fermentation was the $104.4 \mathrm{~g} / \mathrm{L}$ produced using an engineered E. coli strain, with a yield of $1.09 \mathrm{~mol} / \mathrm{mol}(0.9 \mathrm{~g} / \mathrm{g})$ of glycerol [31].

On the other hand, citric acid generation from waste glycerol also represents a promising conversion route that can be achieved by yeast $[60,61]$. Strains of $Y$. lipolytica have been investigated as an alternative to citric acid production by A. niger. Although concentrations achieved are still lower than the concentrations from the commercialized process using glucose as substrate [150,151], economic analysis suggests that it is more profitable to generate value-added products like 1,3-PDO (\$1.8 per kg [149]) and citric acid (\$1.2 to 3.2 per $\mathrm{kg}$ ) from waste glycerol $(\$ 0.11$ per $\mathrm{kg}$ ) $[60,61,152]$.

One of the most challenging elements of the microbial conversion of waste glycerol to water-soluble products is downstream separation and purification, but microbial electrochemical technologies like MECs and MFCs have the potential to efficiently overcome this problem. Electrical power produced from waste glycerol requires no extra cost associated with separation or purification. It was estimated that the electrical power generated from waste glycerol by MFCs may be worth a total value of $\$ 98.4$ million per year [77], a number that could be increased further by optimizing MFC designs for current generation. Similarly, as a gaseous product with low water solubility, hydrogen can be separated from reaction broth with no extensive separation cost regardless of hurdles in storage and transportation [153]. Current hydrogen production is dominated by steam reformation of natural gas, producing hydrogen at a cost ranging from \$1.10 to \$1.24 [154]. High hydrogen yields have been demonstrated using a photo-fermentative bacterium ( $6 \mathrm{~mol} / \mathrm{mol}$ glycerol) [51]. However, the need for light may complicate the reactor design, increasing the difficulty in scaling-up for commercial applications. Under dark-fermentation, low hydrogen yields $(0.28-0.96 \mathrm{~mol} / \mathrm{mol})$ are likely to be caused due to inefficient use of secondary metabolites such as acetate, lactate, and ethanol [23,52-55]. Through the use of an MEC design these secondary metabolites were able to be further utilized [155-157], and higher hydrogen yields (3.6-5.4 $\mathrm{mol} / \mathrm{mol}$ glycerol) closer to the theoretical yields can be achieved 
with a relatively low investment of energy compared to dark fermentation $[23,79,80,158]$. Further research is needed to demonstrate the ability to efficiently scale-up promising waste glycerol to hydrogen conversion technologies, as well as life cycle analyses comparing these technologies to current stream reformation techniques.

In summary, waste glycerol represents a carbon source that is widely available at relatively low-cost and potentially suitable for many applications. Although constraints are still largely present for practical utilization of waste glycerol from biodiesel plants, advancements have been made over the past decade that warrant further research in this fascinating area. Future advancements in this field could bring great social, economic and environmental benefits to society.

\section{Acknowledgements}

The authors would like to acknowledge support from the USA National Science Foundation (CBET 0955124).

\section{Conflicts of Interest}

The authors declare no conflict of interest.

\section{References}

1. Yang, F.X.; Hanna, M.A.; Sun, R.C. Value-added uses for crude glycerol-A byproduct of biodiesel production. Biotechnol. Biofuels 2012, 5, doi:10.1186/1754-6834-5-13.

2. Monthly Biodiesel Production Report; U.S. Energy Information Administration: Washington, DC, USA, 2013.

3. Moser, B.R. Biodiesel Production, Properties, and Feedstocks. In Biofuels; Tomes, D., Lakshmanan, P., Songstad, D., Eds.; Springer: New York, NY, USA, 2011; pp. 285-347.

4. Hu, S.J.; Luo, X.L.; Wan, C.X.; Li, Y.B. Characterization of crude glycerol from biodiesel plants. J. Agric. Food Chem. 2012, 60, 5915-5921.

5. Christoph, R.; Schmidt, B.; Steinberner, U.; Dilla, W.; Karinen, R. Glycerol. In Ullmann's Encyclopedia of Industrial Chemistry; Morrison, L.R., Ed.;Wiley: New York, NY, USA, 2006.

6. Yazdani, S.S.; Gonzalez, R. Anaerobic fermentation of glycerol: A path to economic viability for the biofuels industry. Curr. Opin. Biotech. 2007, 18, 213-219.

7. Kerr, B.; Dozier, W.; Bregendahl, K. Nutritional Value of Crude Glycerin for Nonruminants. In Proceedings of the 23rd Annual Carolina Swine Nutrition Conference, Raleigh, NC, USA, 13 November 2007; pp. 6-18.

8. Bohon, M.D.; Metzger, B.A.; Linak, W.P.; King, C.J.; Roberts, W.L. Glycerol combustion and emissions. Proc. Combust. Inst. 2011, 33, 2717-2724.

9. Johnson, D.T.; Taconi, K.A. The glycerin glut: Options for the value-added conversion of crude glycerol resulting from biodiesel production. Environ. Prog. 2007, 26, 338-348.

10. Siles, J.A.; Martín, M.A.; Chica, A.F.; Martín, A. Anaerobic co-digestion of glycerol and wastewater derived from biodiesel manufacturing. Bioresour. Technol. 2010, 101, 6315-6321.

11. Lammers, P.J.; Kerr, B.J.; Weber, T.E.; Bregendahl, K.; Lonergan, S.M.; Prusa, K.J.; Ahn, D.U.; Stoffregen, W.C.; Dozier, W.A.; Honeyman, M.S. Growth performance, carcass characteristics, 
meat quality, and tissue histology of growing pigs fed crude glycerin-supplemented diets. J. Anim. Sci. 2008, 86, 2962-2970.

12. Lin, E.C.C. Glycerol dissmilation and its regulation in bacteria. Annu. Rev. Microbiol. 1976, 30, 535-578.

13. Neijssel, O.M.; Hueting, S.; Crabbendam, K.J.; Tempest, D.W. Dual pathways of glycerol assimilation in Klebsiella aerogenes NCIB 418. Arch. Microbiol. 1975, 104, 83-87.

14. Abad, S.; Turon, X. Valorization of biodiesel derived glycerol as a carbon source to obtain added-value metabolites: Focus on polyunsaturated fatty acids. Biotechnol. Adv. 2012, 30, 733-741.

15. Fan, X.H.; Burton, R.; Zhou, Y.C. Glycerol (byproduct of biodiesel production) as a source for fuels and chemicals. Open Fuels Energy J. 2010, 3, 17-22.

16. Imhoff, J.F. Enterobacteriales. In Bergey's Manual ${ }^{\circledR}$ of Systematic Bacteriology; Brenner, D.J., Krieg, N.R., Staley, J.T., Garrity, G.M., Boone, D.R., Vos, P., Goodfellow, M., Rainey, F.A., Schleifer, K.-H., Eds.; Springer: New York, NY, USA, 2005; pp. 587-850.

17. Da Silva, G.P.; Mack, M.; Contiero, J. Glycerol: A promising and abundant carbon source for industrial microbiology. Biotechnol. Adv. 2009, 27, 30-39.

18. Murarka, A.; Dharmadi, Y.; Yazdani, S.S.; Gonzalez, R. Fermentative utilization of glycerol by Escherichia coli and its implications for the production of fuels and chemicals. Appl. Environ. Microbiol. 2008, 74, 1124-1135.

19. Braun, T.; Philippsen, A.; Wirtz, S.; Borgnia, M.J.; Agre, P.; Kühlbrandt, W.; Engel, A.; Stahlberg, H. The $3.7 \AA$ projection map of the glycerol facilitator glpf: A variant of the aquaporin tetramer. EMBO Rep. 2000, 1, 183-189.

20. Trinh, C.T.; Srienc, F. Metabolic engineering of Escherichia coli for efficient conversion of glycerol to ethanol. Appl. Environ. Microbiol. 2009, 75, 6696-6705.

21. Bouvet, O.M.M.; Lenormand, P.; Ageron, E.; Grimont, P.A.D. Taxonomic diversity of anaerobic glycerol dissimilation in the Enterobacteriaceae. Res. Microbiol. 1995, 146, 279-290.

22. Gonzalez, R.; Murarka, A.; Dharmadi, Y.; Yazdani, S.S. A new model for the anaerobic fermentation of glycerol in enteric bacteria: Trunk and auxiliary pathways in Escherichia coli. Metab. Eng. 2008, 10, 234-245.

23. Selembo, P.A.; Perez, J.M.; Lloyd, W.A.; Logan, B.E. Enhanced hydrogen and 1,3-propanediol production from glycerol by fermentation using mixed cultures. Biotechnol. Bioeng. 2009, 104, 1098-1106.

24. Chen, X.; Zhou, L.; Tian, K.; Kumar, A.; Singh, S.; Prior, B.A.; Wang, Z. Metabolic engineering of Escherichia coli: A sustainable industrial platform for bio-based chemical production. Biotechnol. Adv. 2013, in press.

25. Cardona, C.A.; Sánchez, Ó.J. Fuel ethanol production: Process design trends and integration opportunities. Bioresour. Technol. 2007, 98, 2415-2457.

26. Yazdani, S.S.; Gonzalez, R. Engineering Escherichia coli for the efficient conversion of glycerol to ethanol and co-products. Metab. Eng. 2008, 10, 340-351.

27. Hong, A.-A.; Cheng, K.-K.; Peng, F.; Zhou, S.; Sun, Y.; Liu, C.-M.; Liu, D.-H. Strain isolation and optimization of process parameters for bioconversion of glycerol to lactic acid. J. Chem. Technol. Biotechnol. 2009, 84, 1576-1581. 
28. Mazumdar, S.; Clomburg, J.M.; Gonzalez, R. Escherichia coli strains engineered for homofermentative production of D-lactic acid from glycerol. Appl. Environ. Microbiol. 2010, 76, 4327-4336.

29. Mazumdar, S.; Blankschien, M.D.; Clomburg, J.M.; Gonzalez, R. Efficient synthesis of L-lactic acid from glycerol by metabolically engineered Escherichia coli. Microb. Cell Fact. 2013, 12, doi:10.1186/1475-2859-12-7.

30. Clomburg, J.M.; Gonzalez, R. Metabolic engineering of Escherichia coli for the production of 1,2-propanediol from glycerol. Biotechnol. Bioeng. 2011, 108, 867-879.

31. Tang, X.; Tan, Y.; Zhu, H.; Zhao, K.; Shen, W. Microbial conversion of glycerol to 1,3-propanediol by an engineered strain of Escherichia coli. Appl. Environ. Microbiol. 2009, 75, 1628-1634.

32. Zhang, X.; Shanmugam, K.T.; Ingram, L.O. Fermentation of glycerol to succinate by metabolically engineered strains of Escherichia coli. Appl. Environ. Microbiol. 2010, 76, 2397-2401.

33. Zhao, Y.-N.; Chen, G.; Yao, S.-J. Microbial production of 1,3-propanediol from glycerol by encapsulated Klebsiella pneumoniae. Biochem. Eng. J. 2006, 32, 93-99.

34. Cheng, K.-K.; Zhang, J.-A.; Liu, D.-H.; Sun, Y.; Liu, H.-J.; Yang, M.-D.; Xu, J.-M. Pilot-scale production of 1,3-propanediol using Klebsiella pneumoniae. Process Biochem. 2007, 42, 740-744.

35. Yang, G.; Tian, J.; Li, J. Fermentation of 1,3-propanediol by a lactate deficient mutant of Klebsiella oxytoca under microaerobic conditions. Appl. Microbiol. Biotechnol. 2007, 73, 1017-1024.

36. Zhang, Y.; Li, Y.; Du, C.; Liu, M.; Cao, Z. Inactivation of aldehyde dehydrogenase: A key factor for engineering 1,3-propanediol production by Klebsiella pneumoniae. Metab. Eng. 2006, 8, 578-586.

37. Petrov, K.; Petrova, P. High production of 2,3-butanediol from glycerol by Klebsiella pneumoniae G31. Appl. Microbiol. Biotechnol. 2009, 84, 659-665.

38. Oh, B.-R.; Seo, J.-W.; Heo, S.-Y.; Hong, W.-K.; Luo, L.H.; Kim, S.; Kwon, O.; Sohn, J.-H.; Joe, M.-H.; Park, D.-H.; et al. Enhancement of ethanol production from glycerol in a Klebsiella pneumoniae mutant strain by the inactivation of lactate dehydrogenase. Process Biochem. 2012, 47, 156-159.

39. Metsoviti, M.; Zeng, A.-P.; Koutinas, A.A.; Papanikolaou, S. Enhanced 1,3-propanediol production by a newly isolated Citrobacter freundii strain cultivated on biodiesel-derived waste glycerol through sterile and non-sterile bioprocesses. J. Biotechnol. 2013, 163, 408-418.

40. Maervoet, V.E.T.; Beauprez, J.; de Maeseneire, S.L.; Soetaert, W.K.; de Mey, M. Citrobacter werkmanii, a new candidate for the production of 1,3-propanediol: Strain selection and carbon source optimization. Green Chem. 2012, 14, 2168-2178.

41. Maru, B.T.; Constanti, M.; Stchigel, A.M.; Medina, F.; Sueiras, J.E. Biohydrogen production by dark fermentation of glycerol using Enterobacter and Citrobacter sp. Biotechnol. Prog. 2013, 29, 31-38.

42. Yang, C.; Jiang, P.; Xiao, S.; Zhang, C.; Lou, K.; Xing, X.-H. Fed-batch fermentation of recombinant Citrobacter freundii with expression of a violacein-synthesizing gene cluster for efficient violacein production from glycerol. Biochem. Eng. J. 2011, 57, 55-62. 
43. González-Pajuelo, M.; Andrade, J.C.; Vasconcelos, I. Production of 1,3-Propanediol by Clostridium butyricum VPI 3266 in continuous cultures with high yield and productivity. J. Ind. Microbiol. Biotechnol. 2005, 32, 391-396.

44. Wilkens, E.; Ringel, A.K.; Hortig, D.; Willke, T.; Vorlop, K.-D. High-level production of 1,3-propanediol from crude glycerol by Clostridium butyricum AKR102a. Appl. Microbiol. Biotechnol. 2012, 93, 1057-1063.

45. Chatzifragkou, A.; Papanikolaou, S.; Dietz, D.; Doulgeraki, A.I.; Nychas, G.-J.E.; Zeng, A.-P. Production of 1,3-propanediol by Clostridium butyricu growing on biodiesel-derived crude glycerol through a non-sterilized fermentation process. Appl. Microbiol. Biotechnol. 2011, 91, 101-112.

46. González-Pajuelo, M.; Meynial-Salles, I.; Mendes, F.; Andrade, J.C.; Vasconcelos, I.; Soucaille, P. Metabolic engineering of Clostridium acetobutylicum for the industrial production of 1,3-propanediol from glycerol. Metab. Eng. 2005, 7, 329-336.

47. Khanna, S.; Goyal, A.; Moholkar, V.S. Production of n-butanol from biodiesel derived crude glycerol using Clostridium pasteurianum immobilized on Amberlite. Fuel 2011, 112, 557-561.

48. Jensen, T.Ø.; Kvist, T.; Mikkelsen, M.J.; Christensen, P.V.; Westermann, P. Fermentation of crude glycerol from biodiesel production by Clostridium pasteurianum. J. Ind. Microbiol. Biotechnol. 2012, 39, 709-717.

49. Zhang, A.; Yang, S.-T. Propionic acid production from glycerol by metabolically engineered Propionibacterium acidipropionici. Process Biochem. 2009, 44, 1346-1351.

50. Ruhal, R.; Choudhury, B. Improved trehalose production from biodiesel waste using parent and osmotically sensitive mutant of Propionibacterium freudenreichii subsp. shermanii under aerobic conditions. J. Ind. Microbiol. Biotechnol. 2012, 39, 1153-1160.

51. Sabourin-Provost, G.; Hallenbeck, P.C. High yield conversion of a crude glycerol fraction from biodiesel production to hydrogen by photofermentation. Bioresour. Technol. 2009, 100, 3513-3517.

52. Gupta, A.; Murarka, A.; Campbell, P.; Gonzalez, R. Anaerobic fermentation of glycerol in Paenibacillus macerans: Metabolic pathways and environmental determinants. Appl. Environ. Microbiol. 2009, 75, 5871-5883.

53. Sittijunda, S.; Reungsang, A. Media optimization for biohydrogen production from waste glycerol by anaerobic thermophilic mixed cultures. Int. J. Hydrog. Energy 2012, 37, 15473-15482.

54. Varrone, C.; Giussani, B.; Izzo, G.; Massini, G.; Marone, A.; Signorini, A.; Wang, A. Statistical optimization of biohydrogen and ethanol production from crude glycerol by microbial mixed culture. Int. J. Hydrog. Energy 2012, 37, 16479-16488.

55. Temudo, M.F.; Poldermans, R.; Kleerebezem, R.; van Loosdrecht, M.C.M. Glycerol fermentation by (open) mixed cultures: A chemostat study. Biotechnol. Bioeng. 2008, 100, 1088-1098.

56. Fountoulakis, M.S.; Manios, T. Enhanced methane and hydrogen production from municipal solid waste and agro-industrial by-products co-digested with crude glycerol. Bioresour. Technol. 2009, 100, 3043-3047.

57. Cavalheiro, J.M.B.T.; de Almeida, M.C.M.D.; Grandfils, C.; da Fonseca, M.M.R. Poly(3-hydroxybutyrate) production by Cupriavidus necator using waste glycerol. Process Biochem. 2009, 44, 509-515. 
58. Ibrahim, M.H.A.; Steinbüchel, A. Zobellella denitrificans strain MW1, a newly isolated bacterium suitable for poly(3-hydroxybutyrate) production from glycerol. J. Appl. Microbiol. 2010, 108, 214-225.

59. Kenny, S.T.; Runic, J.N.; Kaminsky, W.; Woods, T.; Babu, R.P.; O’Connor, K.E. Development of a bioprocess to convert PET derived terephthalic acid and biodiesel derived glycerol to medium chain length polyhydroxyalkanoate. Appl. Microbiol. Biotechnol. 2012, 95, 623-633.

60. Imandi, S.B.; Bandaru, V.R.; Somalanka, S.R.; Garapati, H.R. Optimization of medium constituents for the production of citric acid from byproduct glycerol using Doehlert experimental design. Enzym. Microb. Technol. 2007, 40, 1367-1372.

61. Rywińska, A.; Rymowicz, W.; Żarowska, B.; Wojtatowicz, M. Biosynthesis of citric acid from glycerol by acetate mutants of Yarrowia lipolytica in fed-batch fermentation. Food Technol. Biotechnol. 2009, 47, 1-6.

62. Ashby, R.; Nuñez, A.; Solaiman, D.; Foglia, T. Sophorolipid biosynthesis from a biodiesel co-product stream. J. Am. Oil Chem. Soc. 2005, 82, 625-630.

63. Morita, T.; Konishi, M.; Fukuoka, T.; Imura, T.; Kitamoto, D. Microbial conversion of glycerol into glycolipid biosurfactants, mannosylerythritol lipids, by a basidiomycete yeast, Pseudozyma antarctica JCM 10317 ${ }^{\mathrm{T}}$. J. Biosci. Bioeng. 2007, 104, 78-81.

64. Liang, Y.; Cui, Y.; Trushenski, J.; Blackburn, J.W. Converting crude glycerol derived from yellow grease to lipids through yeast fermentation. Bioresour. Technol. 2010, 101, 7581-7586.

65. Yen, H.-W.; Yang, Y.-C.; Yu, Y.-H. Using crude glycerol and thin stillage for the production of microbial lipids through the cultivation of Rhodotorula glutinis. J. Biosci. Bioeng. 2012, 114, 453-456.

66. Valduga, E.; Tatsch, P.O.; Tiggemann, L.; Zeni, J.; Colet, R.; Cansian, J.M.; Treichel, H.; Luccio, M. Evaluation of the conditions of carotenoids production in a synthetic medium by Sporidiobolus salmonicolor (CBS 2636) in a bioreactor. Int. J. Food Sci. Technol. 2009, 44, 2445-2451.

67. Yu, K.O.; Kim, S.W.; Han, S.O. Engineering of glycerol utilization pathway for ethanol production by Saccharomyces cerevisiae. Bioresour. Technol. 2010, 101, 4157-4161.

68. Jung, J.Y.; Yun, H.S.; Lee, J.W.; Oh, M.K. Production of 1,2-propanediol from glycerol in Saccharomyces cerevisiae. J. Microbiol. Biotechnol. 2011, 21, 846-853.

69. André, A.; Diamantopoulou, P.; Philippoussis, A.; Sarris, D.; Komaitis, M.; Papanikolaou, S. Biotechnological conversions of bio-diesel derived waste glycerol into added-value compounds by higher fungi: Production of biomass, single cell oil and oxalic acid. Ind. Crop. Prod. 2010, 31, 407-416.

70. Marchand, K.; Lubitz, W.; Nicol, R. Utilization of biodiesel derived crude glycerol by fungal isolates for biomass and single cell oil production. J. Biobased. Mater. Bio. 2013, 7, 415-419.

71. Chatzifragkou, A.; Makri, A.; Belka, A.; Bellou, S.; Mavrou, M.; Mastoridou, M.; Mystrioti, P.; Onjaro, G.; Aggelis, G.; Papanikolaou, S. Biotechnological conversions of biodiesel derived waste glycerol by yeast and fungal species. Energy 2011, 36, 1097-1108.

72. Athalye, S.K.; Garcia, R.A.; Wen, Z. Use of biodiesel-derived crude glycerol for producing eicosapentaenoic acid (EPA) by the fungus Pythium irregulare. J. Agric. Food Chem. 2009, 57, 2739-2744. 
73. Mantzouridou, F.; Naziri, E.; Tsimidou, M.Z. Industrial glycerol as a supplementary carbon source in the production of $\beta$-carotene by Blakeslea trispora. J. Agric. Food Chem. 2008, 56, 2668-2675.

74. Chi, Z.; Pyle, D.; Wen, Z.; Frear, C.; Chen, S. A laboratory study of producing docosahexaenoic acid from biodiesel-waste glycerol by microalgal fermentation. Process Biochem. 2007, 42, $1537-1545$.

75. Nimje, V.R.; Chen, C.-Y.; Chen, C.-C.; Chen, H.-R.; Tseng, M.-J.; Jean, J.-S.; Chang, Y.-F. Glycerol degradation in single-chamber microbial fuel cells. Bioresour. Technol. 2011, 102, 2629-2634.

76. Feng, Y.; Yang, Q.; Wang, X.; Liu, Y.; Lee, H.; Ren, N. Treatment of biodiesel production wastes with simultaneous electricity generation using a single-chamber microbial fuel cell. Bioresour. Technol. 2011, 102, 411-415.

77. Sharma, Y.; Parnas, R.; Li, B. Bioenergy production from glycerol in hydrogen producing bioreactors (HPBs) and microbial fuel cells (MFCs). Int. J. Hydrog. Energy 2011, 36, 3853-3861.

78. Sakai, S.; Yagishita, T. Microbial production of hydrogen and ethanol from glycerol-containing wastes discharged from a biodiesel fuel production plant in a bioelectrochemical reactor with thionine. Biotechnol. Bioeng. 2007, 98, 340-348.

79. Selembo, P.A.; Perez, J.M.; Lloyd, W.A.; Logan, B.E. High hydrogen production from glycerol or glucose by electrohydrogenesis using microbial electrolysis cells. Int. J. Hydrog. Energy 2009, 34, 5373-5381.

80. Escapa, A.; Manuel, M.F.; Morán, A.; Gómez, X.; Guiot, S.R.; Tartakovsky, B. Hydrogen production from glycerol in a membraneless microbial electrolysis cell. Energy Fuel. 2009, 23, 4612-4618.

81. Hofvendahl, K.; Hahn-Hägerdal, B. Factors affecting the fermentative lactic acid production from renewable resources. Enzym. Microb. Technol. 2000, 26, 87-107.

82. Okano, K.; Tanaka, T.; Ogino, C.; Fukuda, H.; Kondo, A. Biotechnological production of enantiomeric pure lactic acid from renewable resources: Recent achievements, perspectives, and limits. Appl. Microbiol. Biotechnol. 2010, 85, 413-423.

83. John, R.P.; Anisha, G.S.; Nampoothiri, K.M.; Pandey, A. Direct lactic acid fermentation: Focus on simultaneous saccharification and lactic acid production. Biotechnol. Adv. 2009, 27, 145-152.

84. Wee, Y.J.; Yun, J.S.; Park, D.H.; Ryu, H.W. Biotechnological production of L(+)-lactic acid from wood hydrolyzate by batch fermentation of Enterococcus faecalis. Biotechnol. Lett. 2004, $26,71-74$.

85. Huang, L.; Zhu, Y.-L.; Zheng, H.-Y.; Li, Y.-W.; Zeng, Z.-Y. Continuous production of 1,2-propanediol by the selective hydrogenolysis of solvent-free glycerol under mild conditions. J. Chem. Technol. Biotechnol. 2008, 83, 1670-1675.

86. Shelley, S. A renewable route to propylene glycol. Chem. Eng. Prog. 2007, 103, 6-9.

87. Werpy, T.; Petersen, G. Top Value Added Chemical from Biomass; U.S. Department of Energy: Washington, DC, USA, 2004.

88. Chotani, G.; Dodge, T.; Hsu, A.; Kumar, M.; LaDuca, R.; Trimbur, D.; Weyler, W.; Sanford, K. The commercial production of chemicals using pathway engineering. Biochim. Biophys. Acta 2000, 1543, 434-455. 
89. Zhang, Y.; Huang, Z.; Du, C.; Li, Y.; Cao, Z. Introduction of an NADH regeneration system into Klebsiella oxytoca leads to an enhanced oxidative and reductive metabolism of glycerol. Metab. Eng. 2009, 11, 101-106.

90. Celińska, E.; Grajek, W. Biotechnological production of 2,3-butanediol-Current state and prospects. Biotechnol. Adv. 2009, 27, 715-725.

91. Wolf-Dieter, D. Microbial conversion of glycerol to 1,3-propanediol. FEMS Microbiol. Rev. 1995, 16, 143-149.

92. Durán, N.; Menck, C.F.M. Chromobacterium violaceum: A review of pharmacological and industiral perspectives. Crit. Rev. Microbiol. 2001, 27, 201-222.

93. Biebl, H.; Marten, S.; Hippe, H.; Deckwer, W.-D. Glycerol conversion to 1,3-propanediol by newly isolated Clostridia. Appl. Microbiol. Biotechnol. 1992, 36, 592-597.

94. Lee, S.Y.; Park, J.H.; Jang, S.H.; Nielsen, L.K.; Kim, J.; Jung, K.S. Fermentative butanol production by Clostridia. Biotechnol. Bioeng. 2008, 101, 209-228.

95. Boyaval, P.; Corre, C. Production of propionic acid. Lait 1995, 75, 453-461.

96. Danilo, Z. Production of Propionic Acid. U.S. Patent 8,053,602 B2, 8 November 2011.

97. Cardoso, F.S.; Gaspar, P.; Hugenholtz, J.; Ramos, A.; Santos, H. Enhancement of trehalose production in dairy propionibacteria through manipulation of environmental conditions. Int. J. Food Microbiol. 2004, 91, 195-204.

98. Schiraldi, C.; di Lernia, I.; de Rosa, M. Trehalose production: Exploiting novel approaches. Trends Biotechnol. 2002, 20, 420-425.

99. Kongjan, P.; Angelidaki, I. Extreme thermophilic biohydrogen production from wheat straw hydrolysate using mixed culture fermentation: Effect of reactor configuration. Bioresour. Technol. 2010, 101, 7789-7796.

100. Kongjan, P.; Min, B.; Angelidaki, I. Biohydrogen production from xylose at extreme thermophilic temperatures $\left(70{ }^{\circ} \mathrm{C}\right)$ by mixed culture fermentation. Water Res. 2009, 43, 1414-1424.

101. Pflügl, S.; Marx, H.; Mattanovich, D.; Sauer, M. 1,3-Propanediol production from glycerol with Lactobacillus diolivorans. Bioresour. Technol. 2012, 119, 133-140.

102. Keshavarz, T.; Roy, I. Polyhydroxyalkanoates: Bioplastics with a green agenda. Curr. Opin. Microbiol. 2010, 13, 321-326.

103. Valadi, Å.; Granath, K.; Gustafsson, L.; Adler, L. Distinct intracellular localization of Gpd1p and Gpd2p, the two yeast isoforms of $\mathrm{NAD}^{+}$-dependent Glycerol-3-phosphate dehydrogenase, explains their different contributions to redox-driven glycerol production. J. Biol. Chem. 2004, 279, 39677-39685.

104. Adler, L.; Blomberg, A.; Nilsson, A. Glycerol metabolism and osmoregulation in the salt-tolerant yeast Debaryomyces hansenii. J. Bacteriol. 1985, 162, 300-306.

105. André, L.; Nilsson, A.; Adler, L. The role of glycerol in osmotolerance of the yeast Debaryomyces hansenii. J. Gen. Microbiol. 1988, 134, 669-677.

106. Castro, I.M.; Loureiro-Dias, M.C. Glycerol utilization in Fusarium oxysporum var. lini: Regulation of transport and metabolism. J. Gen. Microbiol. 1991, 137, 1497-1502.

107. Gancedo, C.; Gancedo, J.M.; Sols, A. Glycerol metabolism in yeasts. Eur. J. Biochem. 1968, 5, $165-172$. 
108. Nobre, M.F.; da Costa, M.S. The accumulation of polyols by the yeast Debaryomyces hansenii in response to water stress. Can. J. Microbiol. 1985, 31, 1061-1064.

109. Ferreira, C.; van Voorst, F.; Martins, A.; Neves, L.; Oliveira, R.; Kielland-Brandt, M.C.; Lucas, C.; Brandt, A. A member of the sugar transporter family, Stllp is the glycerol $/ \mathrm{H}^{+}$symporter in Saccharomyces cerevisiae. Mol. Biol. Cell. 2005, 16, 2068-2076.

110. Kayingo, G.; Martins, A.; Andrie, R.; Neves, L.; Lucas, C.; Wong, B. A permease encoded by STL1 is required for active glycerol uptake by Candida albicans. Microbiology 2009, 155, $1547-1557$.

111. Nicol, R.W.; Marchand, K.; Lubitz, W.D. Bioconversion of crude glycerol by fungi. Appl. Microbiol. Biotechnol. 2012, 93, 1865-1875.

112. Amaral, P.F.F.; Ferreira, T.F.; Fontes, G.C.; Coelho, M.A.Z. Glycerol valorization: New biotechnological routes. Food Bioprod. Process. 2009, 87, 179-186.

113. Finogenova, T.V.; Morgunov, I.G.; Kamzolova, S.V.; Chernyavskaya, O.G. Organic acid production by the yeast Yarrowia lipolytica: A review of prospects. Appl. Biochem. Microbiol. 2005, 41, 418-425.

114. Xu, D.-B.; Madrid, C.P.; Röhr, M.; Kubicek, C.P. The influence of type and concentration of the carbon source on production of citric acid by Aspergillus niger. Appl. Microbiol. Biotechnol. 1989, 30, 553-558.

115. Amaral, P.F.F.; Coelho, M.A.Z.; Marrucho, I.M.J.; Coutinho, J.A.P. Biosurfactants from Yeasts: Characteristics, Production and Application. In Biosurfactants; Sen, R., Ed.; Springer: New York, NY, USA, 2010; Volume 672, pp. 236-249.

116. Banat, I.M.; Franzetti, A.; Gandolfi, I.; Bestetti, G.; Martinotti, M.G.; Fracchia, L.; Smyth, T.J.; Marchant, R. Microbial biosurfactants production, applications and future potential. Appl. Microbiol. Biotechnol. 2010, 87, 427-444.

117. Makkar, R.S.; Cameotra, S.S.; Banat, I.M. Advances in utilization of renewable substrates for biosurfactant production. AMB Express 2011, 1, doi:10.1186/2191-0855-1-5.

118. Liu, Y.; Koh, C.M.J.; Ji, L. Bioconversion of crude glycerol to glycolipids in Ustilago maydi. Bioresour. Technol. 2011, 102, 3927-3933.

119. Papanikolaou, S.; Komaitis, M.; Aggelis, G. Single cell oil (SCO) production by Mortierella isabellina grown on high-sugar content media. Bioresour. Technol. 2004, 95, 287-291.

120. Gouveia, L.; Empis, J. Relative stabilities of microalgal carotenoids in microalgal extracts, biomass and fish feed: Effect of storage conditions. Innov. Food Sci. Emerg. Technol. 2003, 4, $227-233$.

121. Simopoulos, A.P. Essential fatty acids in health and chronic disease. Am. J. Clin. Nutr. 1999, 70, 560S-569S.

122. Hou, C.T. Production of arachidonic acid and dihomo- $\gamma$-linolenic acid from glycerol by oil-producing filamentous fungi, Mortierella in the ARS culture collection. J. Ind. Microbiol. Biotechnol. 2008, 35, 501-506.

123. Tonon, T.; Harvey, D.; Larson, T.R.; Graham, I.A. Long chain polyunsaturated fatty acid production and partitioning to triacylglycerols in four microalgae. Phytochemistry 2002, 61, $15-24$. 
124. Grima, E.M.; Pérez, J.A.S.; Camacho, F.G.; Medina, A.R.; Giménez, A.G.; López Alonso, D. The production of polyunsaturated fatty acids by microalgae: From strain selection to product purification. Process Biochem. 1995, 30, 711-719.

125. Chisti, Y. Biodiesel from microalgae. Biotechnol. Adv. 2007, 25, 294-306.

126. Ingram, L.O.; Calder, J.A.; van Baalen, C.; Plucker, F.E.; Parker, P.L. Role of reduced exogenous organic compounds in the physiology of the blue-green bacteria (algae): Photoheterotrophic growth of a "heterotrophic" blue-green bacterium. J. Bacteriol. 1973, 114, 695-700.

127. Ingram, L.O.; Van Baalen, C.; Calder, J.A. Role of reduced exogenous organic compounds in the physiology of the blue-green bacteria (algae): Photoheterotrophic growth of an "autotrophic" blue-green bacterium. J. Bacteriol. 1973, 114, 701-705.

128. Neilson, A.H.; Lewin, R.A. The uptake and utilization of organic carbon by algae: An essay in comparative biochemistry. Phycologia 1974, 13, 227-264.

129. Villadsen, J.; Nielsen, J.; Lidén, G. Bioreaction Engineering Principles; Springer: New York, NY, USA, 2011.

130. Menzel, K.; Zeng, A.-P.; Deckwer, W.-D. High concentration and productivity of 1,3-propanediol from continuous fermentation of glycerol by Klebsiella pneumoniae. Enzym. Microb. Technol. 1997, 20, 82-86.

131. Gungormusler, M.; Gonen, C.; Azbar, N. Continuous production of 1,3-propanediol using raw glycerol with immobilized Clostridium beijerinckii NRRL B-593 in comparison to suspended culture. Bioprocess Biosyst. Eng. 2011, 34, 727-733.

132. Gungormusler, M.; Gonen, C.; Azbar, N. Use of ceramic-based cell immobilization to produce 1,3-propanediol from biodiesel-derived waste glycerol with Klebsiella pneumoniae. J. Appl. Microbiol. 2011, 111, 1138-1147.

133. Yen, H.-W.; Brune, D.E. Anaerobic co-digestion of algal sludge and waste paper to produce methane. Bioresour. Technol. 2007, 98, 130-134.

134. Yazdani, S.; Mattam, S.; Gonzalez, R. Fuel and Chemical Production from Glycerol, a Biodiesel Waste Product. In Biofuels from Agricultural Wastes and Byproducts; Blaschek, H.P., Ezeji, T.C., Scheffran, J., Eds; Wiley-Blackwell: Oxford, UK, 2010; doi:10.1002/9780813822716.ch6.

135. Astals, S.; Nolla-Ardèvol, V.; Mata-Alvarez, J. Anaerobic co-digestion of pig manure and crude glycerol at mesophilic conditions: Biogas and digestate. Bioresour. Technol. 2012, 110, 63-70.

136. Harnisch, F.; Schröder, U. From MFC to MXC: Chemical and biological cathodes and their potential for microbial bioelectrochemical systems. Chem. Soc. Rev. 2010, 39, 4433-4448.

137. Nevin, K.P.; Hensley, S.A.; Franks, A.E.; Summers, Z.M.; Ou, J.; Woodard, T.L.; Snoeyenbos-West, O.L.; Lovley, D.R. Electrosynthesis of organic compounds from carbon dioxide is catalyzed by a diversity of acetogenic microorganisms. Appl. Environ. Microbiol. 2011, 77, 2882-2886.

138. Logan, B.E. Exoelectrogenic bacteria that power microbial fuel cells. Nat. Rev. Microbiol. 2009, 7, 375-381.

139. Malvankar, N.S.; Lovley, D.R. Microbial nanowires: A new paradigm for biological electron transfer and bioelectronics. ChemSusChem 2012, 5, 1039-1046. 
140. Roden, E.E.; Kappler, A.; Bauer, I.; Jiang, J.; Paul, A.; Stoesser, R.; Konishi, H.; Xu, H. Extracellular electron transfer through microbial reduction of solid-phase humic substances. Nat. Geosci. 2010, 3, 417-421.

141. Lovley, D.R. Powering microbes with electricity: Direct electron transfer from electrodes to microbes. Environ. Microbiol. Rep. 2011, 3, 27-35.

142. Liu, H.; Cheng, S.; Logan, B.E. Production of electricity from acetate or butyrate using a single-chamber microbial fuel cell. Environ. Sci. Technol. 2005, 39, 658-662.

143. Liu, H.; Hu, H.; Chignell, J.; Fan, Y. Microbial electrolysis: Novel technology for hydrogen production from biomass. Biofuels 2010, 1, 129-142.

144. Nevin, K.P.; Richter, H.; Covalla, S.F.; Johnson, J.P.; Woodard, T.L.; Orloff, A.L.; Jia, H.; Zhang, M.; Lovley, D.R. Power output and columbic efficiencies from biofilms of Geobacter sulfurreducens comparable to mixed community microbial fuel cells. Environ. Microbiol. 2008, $10,2505-2514$.

145. Du, Z.; Li, H.; Gu, T. A state of the art review on microbial fuel cells: A promising technology for wastewater treatment and bioenergy. Biotechnol. Adv. 2007, 25, 464-482.

146. Dennis, P.G.; Harnisch, F.; Yeoh, Y.K.; Tyson, G.W.; Rabaey, K. Dynamics of cathode-associated microbial communities and metabolite profiles in a glycerol-fed bioelectrochemical system. Appl. Environ. Microbiol. 2013, 79, 4008-4014.

147. Kraus, G.A. Synthetic methods for the preparation of 1,3-propanediol. CLEAN-Soil Air Water 2008, 36, 648-651.

148. Saxena, R.K.; Anand, P.; Saran, S.; Isar, J. Microbial production of 1,3-propanediol: Recent developments and emerging opportunities. Biotechnol. Adv. 2009, 27, 895-913.

149. Emptage, M.; Haynie, S.L.; Laffend, L.A.; Pucci, J.P.; Whited, G. Process for the Biological Production of 1,3-Propanediol with High Titer. U.S. Patent 7,504,250 B2, 17 March 2009.

150. Nakamura, C.E.; Whited, G.M. Metabolic engineering for the microbial production of 1,3-propanediol. Curr. Opin. Biotechnol. 2003, 14, 454-459.

151. Zeng, A.-P.; Biebl, H. Bulk Chemicals from Biotechnology: The Case of 1,3-Propanediol Production and the New Trends. In Tools and Applications of Biochem. Engineering Science; Schügerl, K., Zeng, A.-P., Aunins, J.G., Bader, A., Bell, W., Biebl, H., Biselli, M., Carrondo, M.J.T., Castilho, L.R., Chang, H.N., et al., Eds.; Springer: Berlin, Germany, 2002; Volume 74, pp. 239-259.

152. Sánchez, Ó.J.; Cardona, C.A. Trends in biotechnological production of fuel ethanol from different feedstocks. Bioresour. Technol. 2008, 99, 5270-5295.

153. Holladay, J.D.; Hu, J.; King, D.L.; Wang, Y. An overview of hydrogen production technologies. Catal. Today 2009, 139, 244-260.

154. Dillich, S.; Ramsden, T.; Melaina, M. Hydrogen Production Cost Using Low-Cost Natural Gas; U.S. Department of Energy: Washington, DC, USA, 2012.

155. Hu, H.; Fan, Y.; Liu, H. Hydrogen production using single-chamber membrane-free microbial electrolysis cells. Water Res. 2008, 42, 4172-4178.

156. Logan, B.E.; Call, D.; Cheng, S.; Hamelers, H.V.M.; Sleutels, T.H.J.A.; Jeremiasse, A.W.; Rozendal, R.A. Microbial electrolysis cells for high yield hydrogen gas production from organic matter. Environ. Sci. Technol. 2008, 42, 8630-8640. 
157. Lu, L.; Ren, N.; Xing, D.; Logan, B.E. Hydrogen production with effluent from an ethanol- $\mathrm{H}_{2}$-coproducing fermentation reactor using a single-chamber microbial electrolysis cell. Biosens. Bioelectron. 2009, 24, 3055-3060.

158. Liu, H.; Grot, S.; Logan, B.E. Electrochemically assisted microbial production of hydrogen from acetate. Environ. Sci. Technol. 2005, 39, 4317-4320.

(C) 2013 by the authors; licensee MDPI, Basel, Switzerland. This article is an open access article distributed under the terms and conditions of the Creative Commons Attribution license (http://creativecommons.org/licenses/by/3.0/). 